\title{
The Archaeobotany of Roman Britain: Current State and Identification of Research Priorities
}

\author{
$B y$ MARIJKE VAN DER VEEN, ALEXANDRA LIVARDA \\ and ALISTAIR HILL
}

\section{INTRODUCTION}

A rchaeobotany is concerned with the study of plant remains (primarily macro-fossils such as grains, seeds, nutshells, and fruit stones) recovered from excavations. These remains are used to reconstruct past agricultural systems, environments and human activity, and in particular to assess the degree of dietary breadth and variability in social access to specific foods. The Roman period in Britain represents a crucial phase in the development of both agriculture and diet, as it was during this time that some 50 or more new foods (mainly fruits, vegetables and herbs) became established, ${ }^{1}$ thus diversifying both the British diet and the British farming system (there is currently no evidence for horticulture or arboriculture in Iron Age Britain).

Accurate reconstructions of agriculture and diet are, of course, entirely dependent on the quality of the dataset available for study. Archaeobotanical data have been collected for many years, but there has not been a systematic assessment of how good the existing body of material actually is for answering questions relating to such reconstructions. ${ }^{2}$ Here such an assessment is presented, lacunae are highlighted, and research priorities are formulated. The coverage for this paper is Britain in the Roman period (the whole of the island, including the area not occupied by Rome). In the methodology section below procedures are explained; then follows a factual description of the available data as of early 2006, followed by the discussion of several matters of concern. The paper concludes by formulating a series of research priorities for future work and recommendations for good practice.

\section{METHODOLOGY}

\section{DATA SELECTION}

Every effort was made to collect all archaeobotanical reports relevant to Britain in the Roman period. To this end bibliographic searches were carried out using the ArchaeoBotanical Computer Database, ${ }^{3}$ the Environmental Archaeology Bibliography, ${ }^{4}$ and the Ancient Monuments Labor-

Van der Veen et al. in press.

Though see M. Jones 1981 and Greig 1991.

ABCD: Tomlinson and Hall 1996; Allan Hall generously provided an updated version.

EAB: Hall 2004 
atory reports from English Heritage. In addition, colleagues across the country were contacted in order to trace recently published and unpublished reports. Data collection stopped in early 2006. All the available reports were consulted and the presence of all food plants (cultivated and wild foods) was recorded, along with information about the exact location (National Grid Reference) and nature of the site, chronology, the number of samples analysed, and mode of preservation of each taxon. Only presence/absence was recorded; no numerical abundance was used, though if a species was particularly abundant, that was noted.

\section{SITE CLASSIFICATION}

To study social differences in access to certain foods the sites were classified into a series of types, which identify broad social and cultural groupings. While the types are broad by necessity, to take account of the size and quality of the database, they are more detailed than those used in previous studies: ${ }^{5}$

$\begin{array}{llll}\text { Rural } & \begin{array}{l}\text { lesser (farmstead, hamlet) } \\ \text { nucleated (village) } \\ \text { élite (villa) }\end{array} & \text { Military } & \begin{array}{l}\text { intramural } \\ \text { extramural (vicus, } \\ \text { town major (colonia, municipium, } \\ \text { civitas capital) }\end{array} \\ \text { town minor ('small' town) } & \text { Ceremonial } & \begin{array}{l}\text { canial (inhumation and } \\ \text { cremation) }\end{array} \\ & & & \begin{array}{l}\text { temple, shrine } \\ \text { industrial, craft centre, } \\ \end{array} \\ & \text { Other } & \text { etc. }\end{array}$

\section{CHRONOLOGICAL SUBDIVISION}

The start- and end-date of each record was recorded, to the level of precision available in the publication/report. Subsequently, each record was allocated a broad chronological phase (Early, Middle, and Late Roman), on the basis of the start-/end-dates available. These phases are defined as follows:

Early Roman records dated to the first century A.D., including those continuing into the second century. Also included are Late Iron Age sites where the occupation continued into the first or early second century A.D.

Middle Roman records dated to the second and third centuries A.D.

Late Roman records dated to the fourth century A.D., including those that started in the third but continued into the fourth century

Roman $\mathrm{m} / \mathrm{l}$ records dated no more specifically than second-fourth centuries A.D.

Roman no dating evidence beyond 'Roman', plus records dated very broadly to the firstthird centuries A.D.

\section{TERMINOLOGY}

In this paper we refer to 'places', 'sites', 'records', and 'occurrences'. 'Places' are geographical locations of past activity, e.g. London. 'Sites' are locations of excavation subdivided by site cat- 
egory. Thus, an excavation where evidence of a major town and a cemetery was found represents two 'sites'. A 'place' may have more than one 'site', e.g. Baltic House, Fennings Wharf, and Hooper Street are all 'sites' in London. This is particularly the case, of course, in large settlements where much excavation has taken place, such as London, York, Carlisle, and Colchester.

'Records' are subsets of sites, representing chronologically and culturally distinct sets of data. For example, the site at Baltic House in London was classified as 'town major', and produced archaeobotanical data from Early, Middle, and Late Roman deposits; this therefore represents three 'records'. If, additionally, a mid-Roman cemetery had been found on the same site, data from the cemetery would have represented a second 'site', as well as a fourth 'record'. Similarly, archaeobotanical data from a fort, consisting of material from both intramural and extramural deposits, would represent two separate 'sites', as well as two 'records'. The 'record' is therefore the smallest unit of analysis and this unit will be used throughout this paper. Where appropriate, how many 'sites' these 'records' originate from (and from how many 'places') will be indicated.

Finally, the term 'occurrence' refers to the occurrence of a particular food plant in a particular mode of preservation. For example, if grape (Vitis vinifera) occurs both in carbonized and waterlogged form at Early Roman Baltic House, then that would count as one 'record', but two 'occurrences' of grape. If grape was also found at Middle Roman Baltic House, but here only waterlogged, then we would have two 'records' of grape, and three 'occurrences' (two waterlogged and one carbonized).

\section{DATABASE}

The dataset currently consists of 639 records (=514 sites). Table 1 and FIGS 1 and 2 show the spread of records over the site categories and phases. Records from rural sites make up c. 50 per

TABLE 1. NUMBER OF RECORDS WITH ARCHAEOBOTANICAL DATA FOR BRITAIN IN THE ROMAN PERIOD, BY SITE TYPE AND PHASE OF OCCUPATION. (ER=EARLY ROMAN; MR=MIDDLE ROMAN; LR=LATE ROMAN; R M/L=ROMAN MID/LATE; R=ROMAN UNDIFFERENTIATED).

$\begin{array}{lrrrrrr} & \text { ER } & \text { MR } & \text { LR } & \text { R m/l } & \text { R } & \text { Total } \\ \text { Military } & & & & & & \\ \text { M - intramural } & 30 & 30 & 17 & 0 & 2 & \mathbf{7 9} \\ \text { M - extramural } & 9 & 13 & 4 & 0 & 3 & \mathbf{2 9} \\ \text { Town } & & & & & & \\ \text { T - major } & 11 & 23 & 24 & 3 & 11 & \mathbf{9 2} \\ \text { T - minor } & 11 & 13 & 13 & 3 & 2 & \mathbf{4 2} \\ \text { Rural } & 7 & 16 & 28 & 1 & 5 & \mathbf{5 7} \\ \text { R - élite } & 19 & 14 & 13 & 4 & 2 & \mathbf{5 2} \\ \text { R - nucleated } & 96 & 37 & 61 & 10 & 24 & \mathbf{2 2 8} \\ \text { R - lesser } & 4 & 5 & 4 & 0 & 0 & \mathbf{1 3} \\ \text { Ceremonial } & 10 & 4 & 5 & 3 & 3 & \mathbf{2 5} \\ \text { C - temple/shrine } & & & & & & \\ \text { C - burial/cremation } & 1 & 0 & 0 & 0 & 0 & \mathbf{1} \\ \text { Other } & 4 & 6 & 7 & 0 & 3 & \mathbf{2 0} \\ \text { O - trading centre } & 1 & 0 & 0 & 0 & 0 & \mathbf{1} \\ \text { O - industrial } & \mathbf{2 2 3} & \mathbf{1 6 1} & \mathbf{1 7 6} & \mathbf{2 4} & \mathbf{5 5} & \mathbf{6 3 9} \\ \text { O - shipwreck } & & & & & & \\ \text { Total } & & & & & \end{array}$




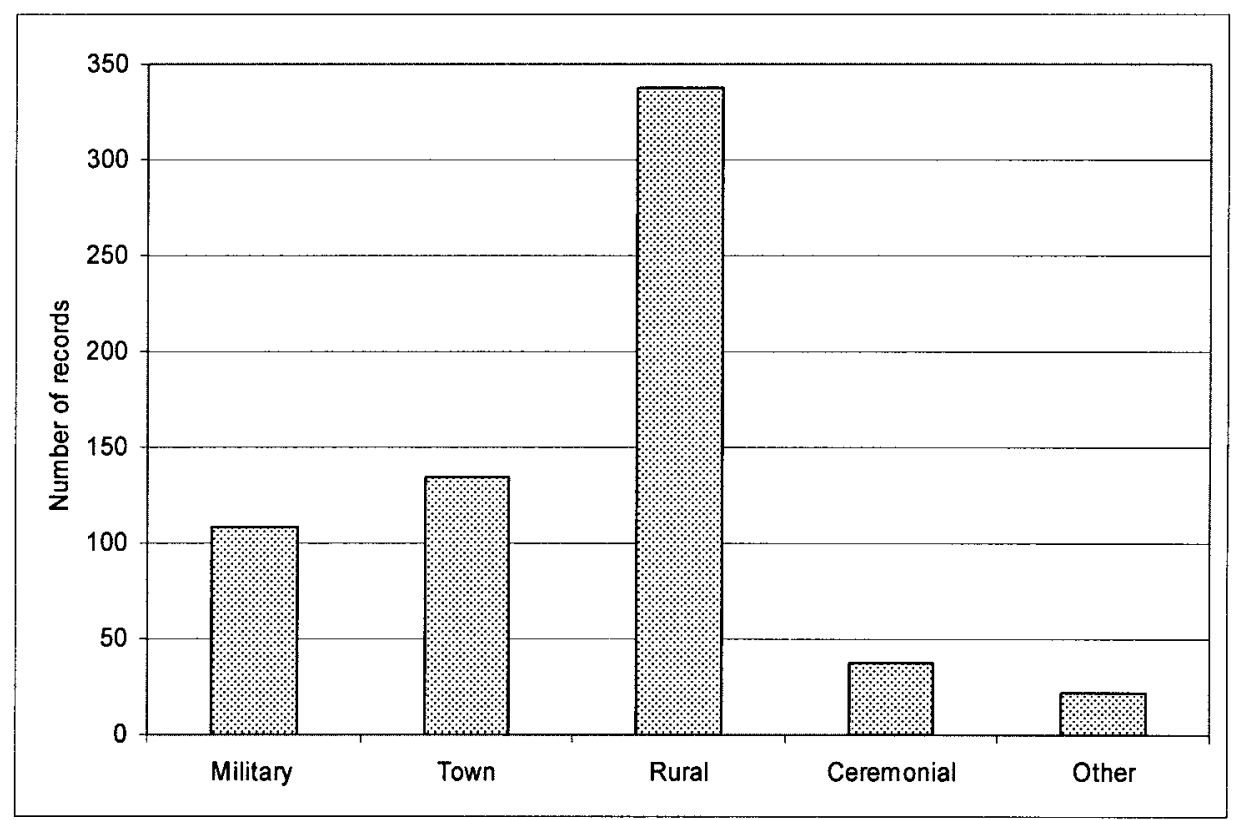

FIG. 1. Number of records with archaeobotanical data by site category $(\mathrm{N}=639)$.

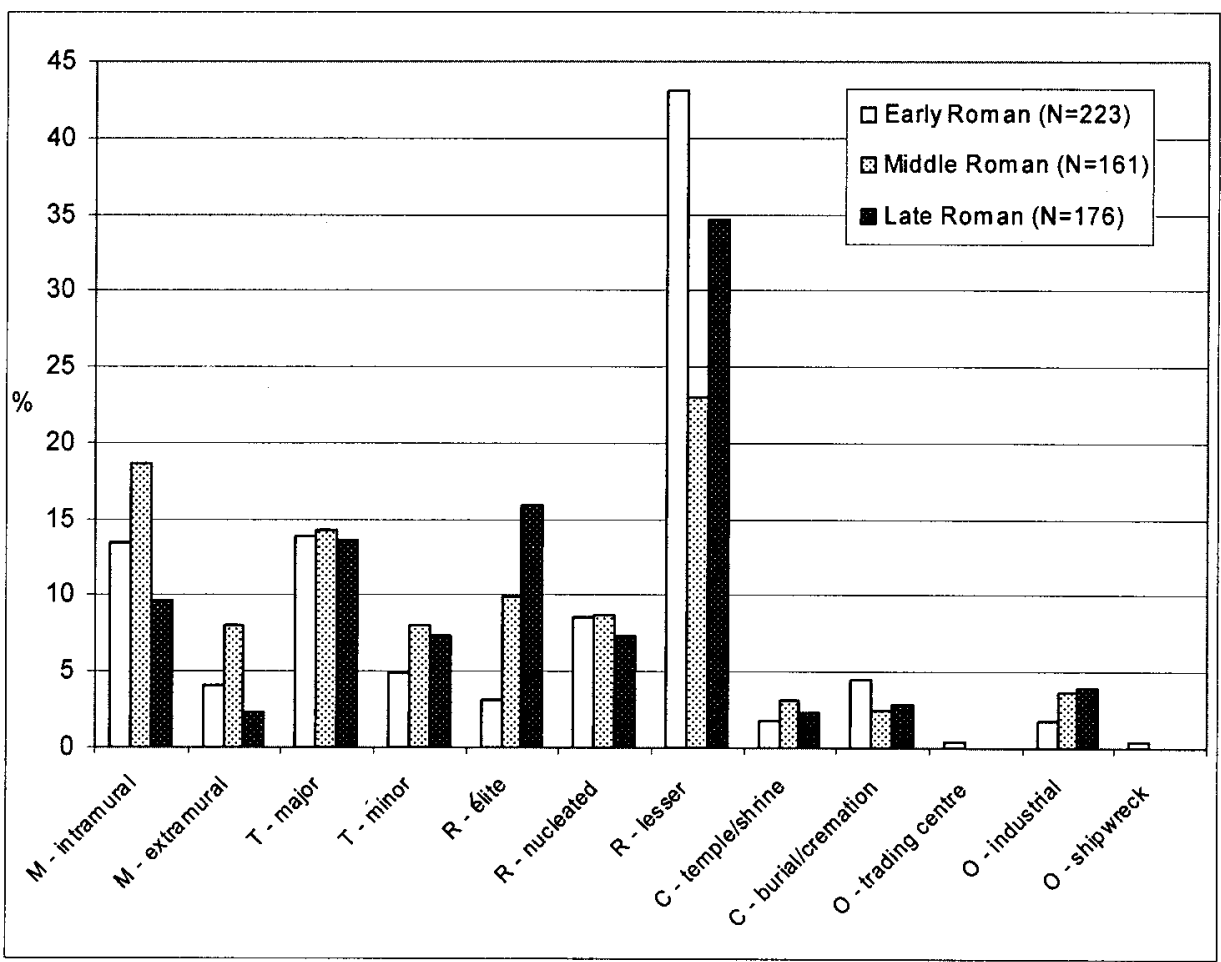

FIG. 2. Relative proportion of records with archaeobotanical data by phase of occupation and site type. 
cent of the total, with rural lesser records the most abundant site type. Records are reasonably well spread across the three phases of occupation, with only 79 records either unphased or allocated a very broad date-range. Most of the poorly-dated records are from rural sites.

In terms of geographical coverage, there is a good distribution of records for Central-Southern and South-Eastern England (FIG. 3), but there are very few records for South-Western and NorthWestern parts of England, for Wales, and for Scotland north of the Antonine Wall. This is all the more apparent when the data are divided by site type and phase of occupation (FIGS 4, 5, 6, 7 and 8 ). There are several parts of the country where there are either no records, or just one or two per $100 \times 100 \mathrm{~km}$ square, preventing reliable inferences about diet or agriculture in those regions. The excavation and archaeobotanical sampling of sites in those regions should thus form a research priority.

In terms of the 'town major' group, there is a strong bias in favour of just one town: London, although York, Colchester and Dorchester are also well represented (Table 2). The advantage is that we have a very good dataset for London, but it is clear that we urgently need datasets from the other major towns.

TABLE 2. NUMBER OF RECORDS WITH ARCHAEOBOTANICAL DATA FOR THE MAJOR TOWN SITES.

$\begin{array}{lrrrrrr} & \text { ER } & \text { MR } & \text { LR } & \mathbf{R ~ m / l} & \mathbf{R} & \text { Total } \\ \text { London } & 18 & 11 & 11 & . & 5 & \mathbf{4 5} \\ \text { York } & 2 & 6 & 4 & . & . & \mathbf{1 2} \\ \text { Colchester } & 5 & 1 & 1 & . & 1 & \mathbf{8} \\ \text { Dorchester } & 3 & . & 1 & 2 & . & \mathbf{6} \\ \text { Leicester } & 2 & 1 & . & 1 & . & \mathbf{4} \\ \text { Lincoln } & . & 1 & 1 & . & 1 & \mathbf{3} \\ \text { Silchester } & . & . & 2 & . & 1 & \mathbf{3} \\ \text { Winchester } & 1 & 1 & 1 & . & . & \mathbf{3} \\ \text { Caerwent } & . & 1 & . & . & 1 & \mathbf{2} \\ \text { Gloucester } & . & . & . & . & 1 & \mathbf{1} \\ \text { St Albans } & . & . & . & . & . & \mathbf{1} \\ \text { Wroxeter } & . & . & 1 & . & . & \mathbf{1} \\ \text { Carmarthen } & . & . & 1 & . & . & \mathbf{1} \\ \text { Cirencester } & . & . & 1 & . & . & \mathbf{1} \\ \text { Brough } & \mathbf{3 1} & \mathbf{2 3} & \mathbf{2 4} & \mathbf{3} & \mathbf{1 1} & \mathbf{9 2} \\ \text { Total } & & & & & \end{array}$

\section{PRESERVATION}

Without some special mechanism for preservation, dead plant tissues on or in the ground normally decay after a number of years. The three most common modes of preservation in Britain (and North-Western Europe) are carbonization, waterlogging, and mineralization. Impressions in pottery and desiccation are rarely if ever encountered in Roman Britain. The mode of preservation matters greatly because the type of plant foods recovered is strongly correlated to the type of preservation encountered at any one site (FIG. 9). Foods such as cereals and pulses are almost exclusively found in carbonized form (apart from exceptional situations such as the Swiss lakeshore villages), while fruits, vegetables, herbs, and oil-rich seeds are 


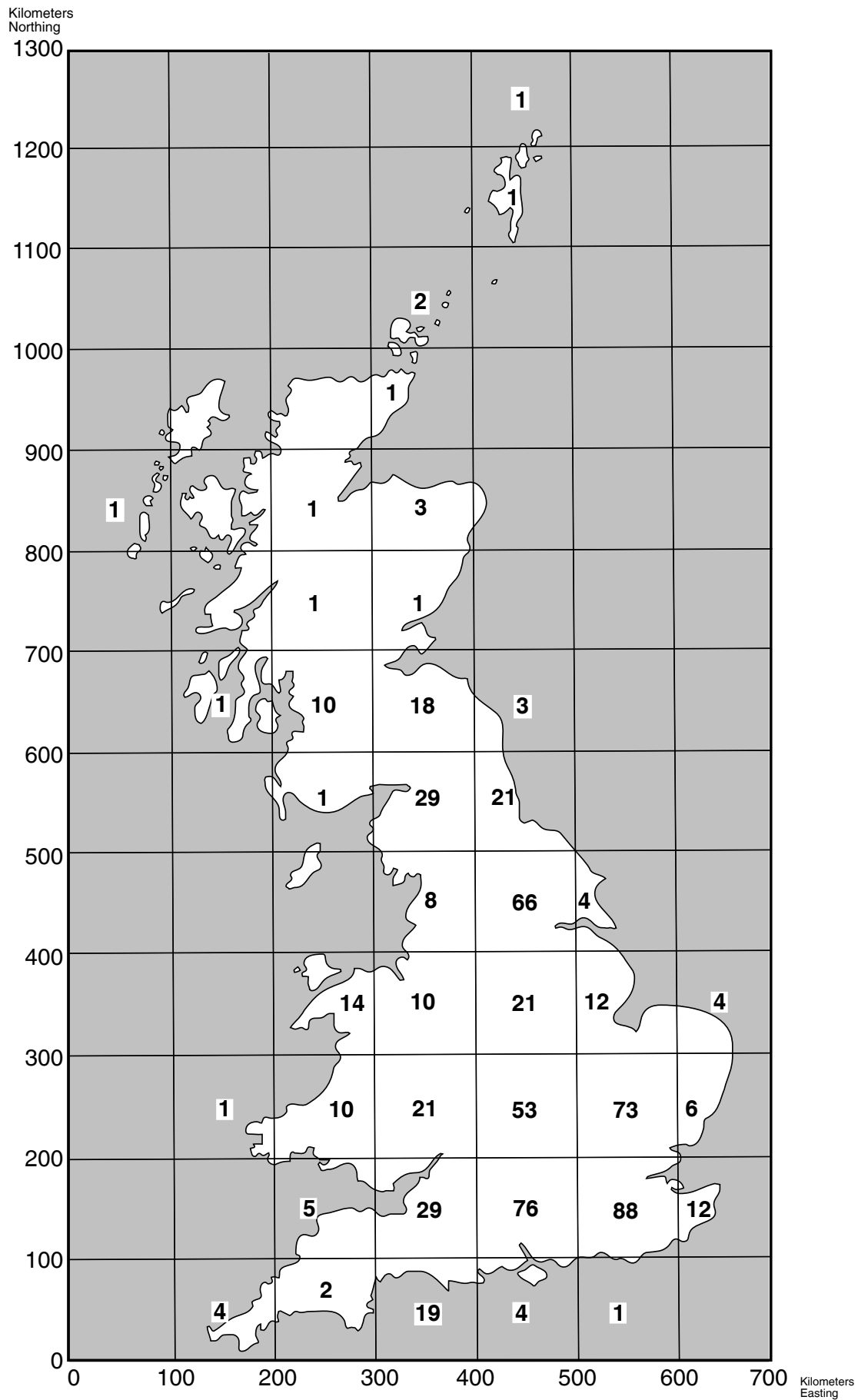

FIG. 3. Geographical distribution of records with archaeobotanical data from Roman Britain. Each square represents an area of $100 \times 100 \mathrm{~km}$. 

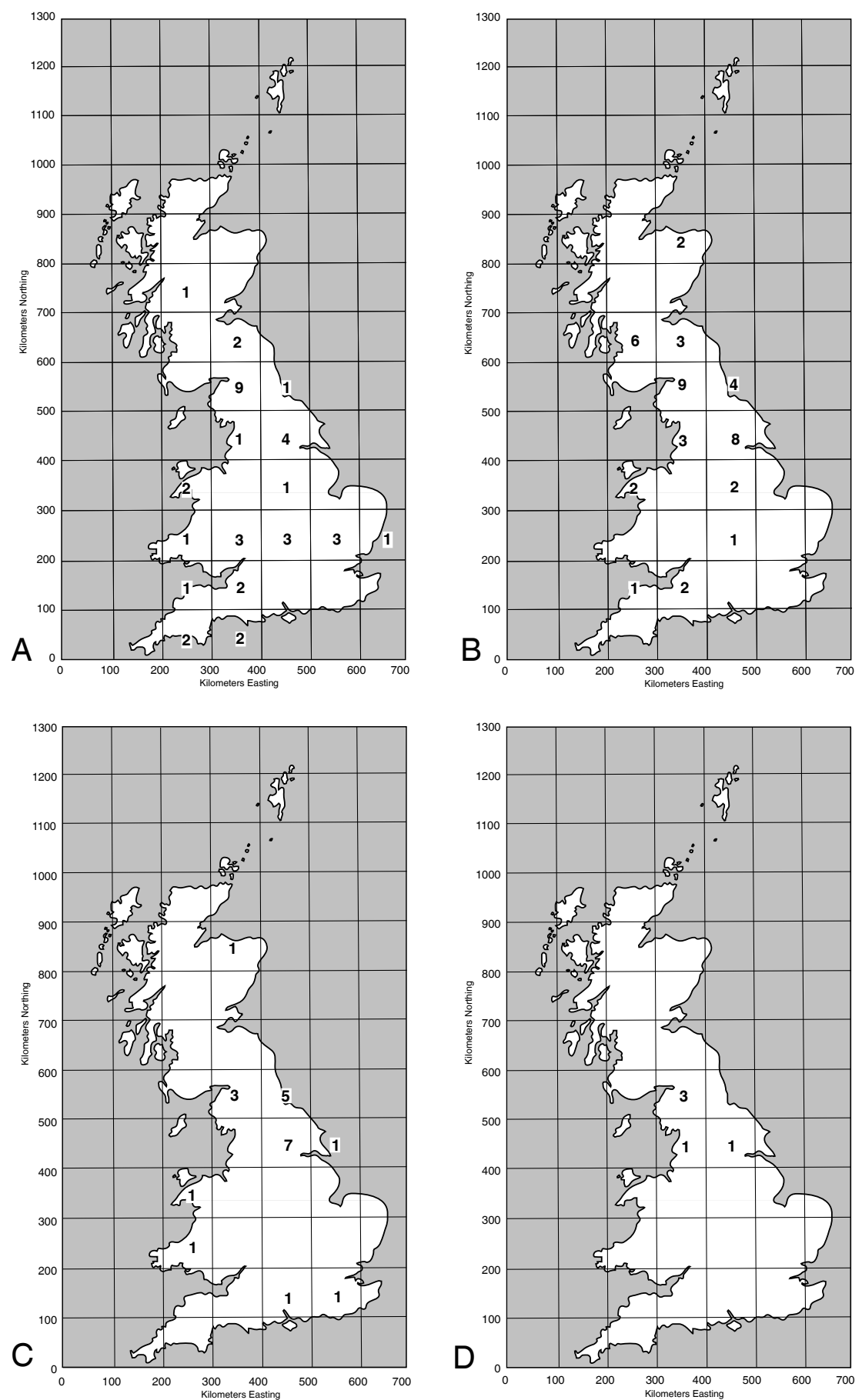

FIG. 4. Geographical distribution of records with archaeobotanical data from military sites, by phase of occupation. A. Early Roman; B. Middle Roman; C. Late Roman; D. Roman mid/late and undifferentiated. 

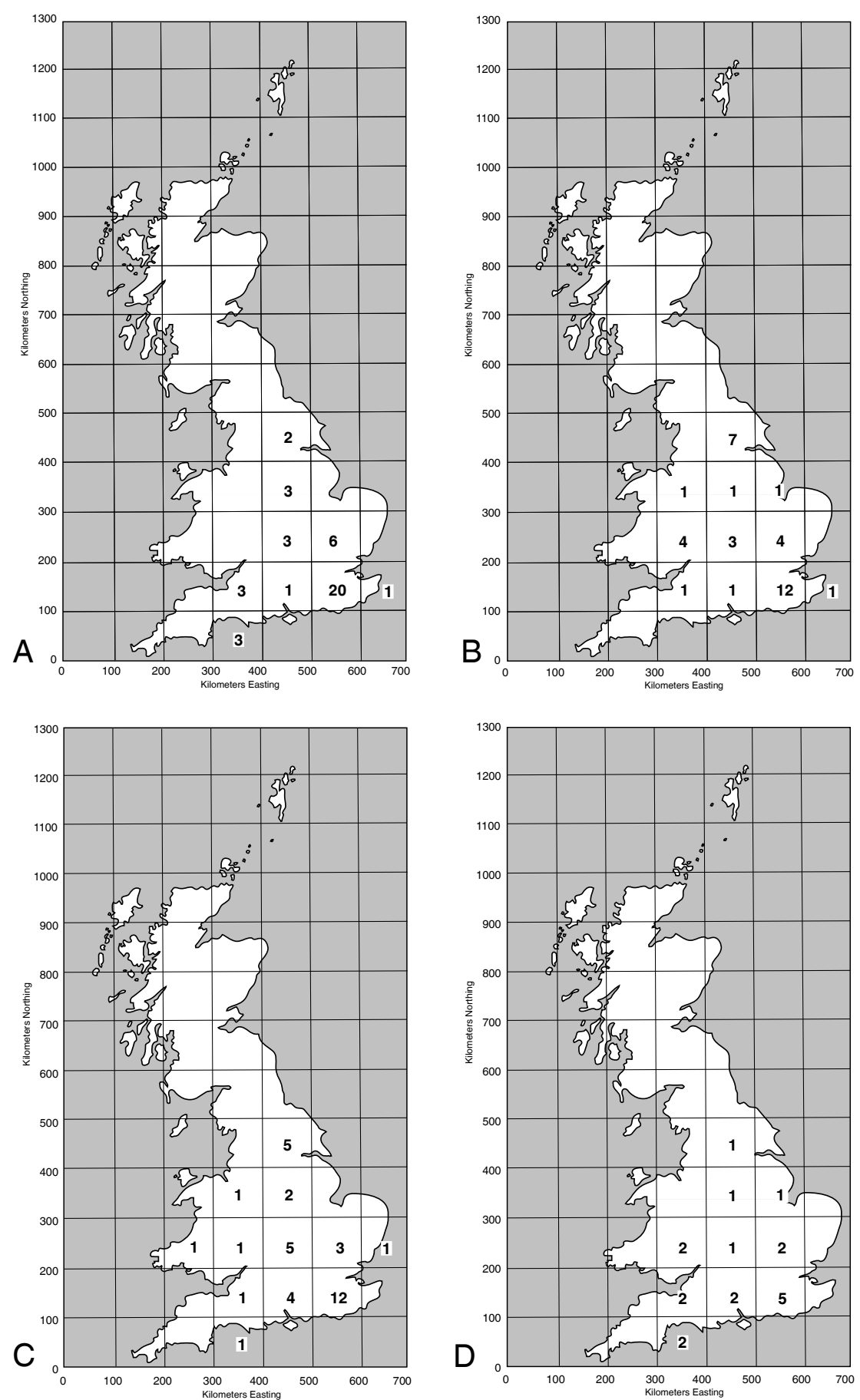

FIG. 5. Geographical distribution of records with archaeobotanical data from towns, by phase of occupation. A. Early Roman; B. Middle Roman; C. Late Roman; D. Roman mid/late and undifferentiated. 

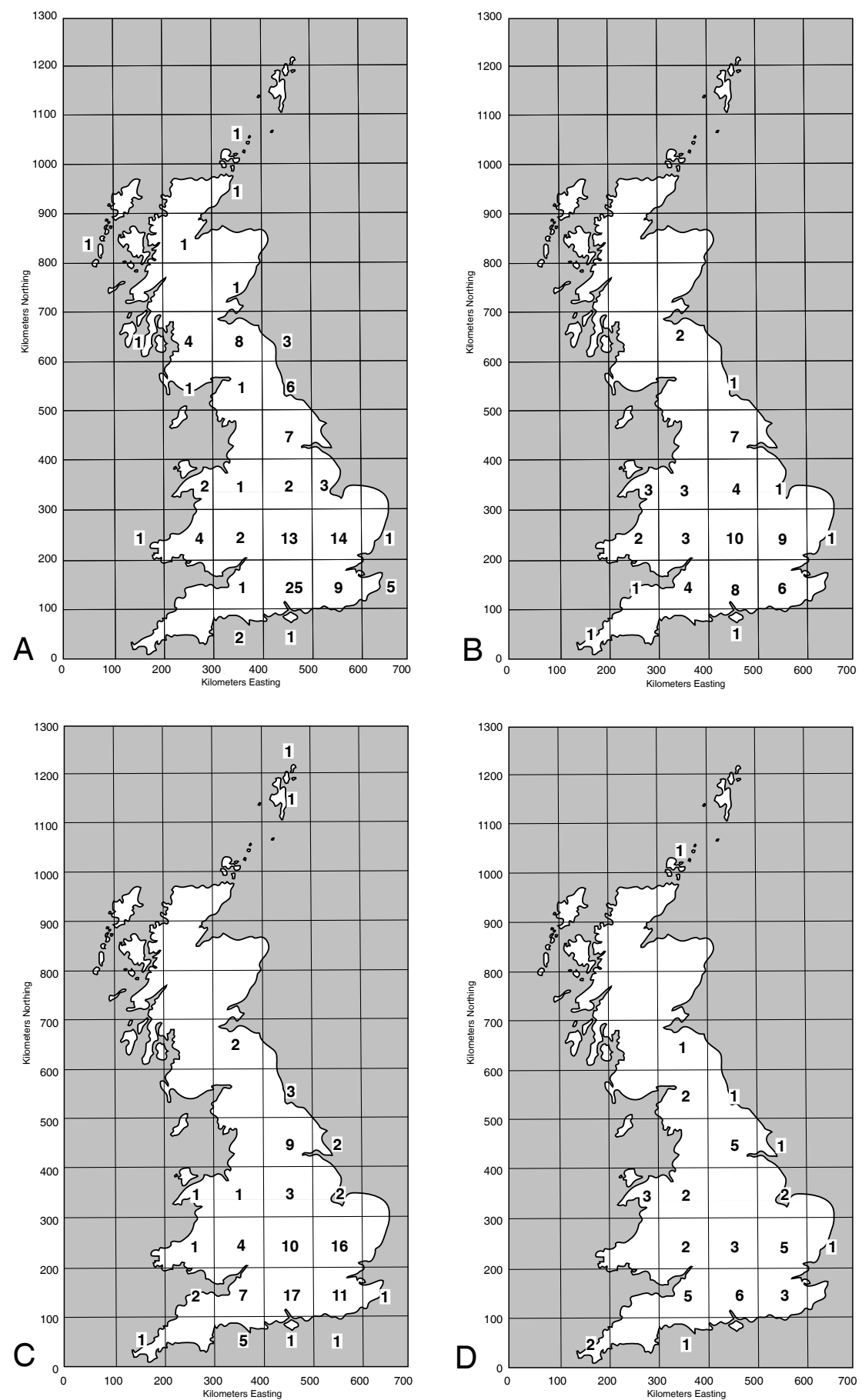

FIG. 6. Geographical distribution of records with archaeobotanical data from rural sites, by phase of occupation. A. Early Roman; B. Middle Roman; C. Late Roman; D. Roman mid/late and undifferentiated. 

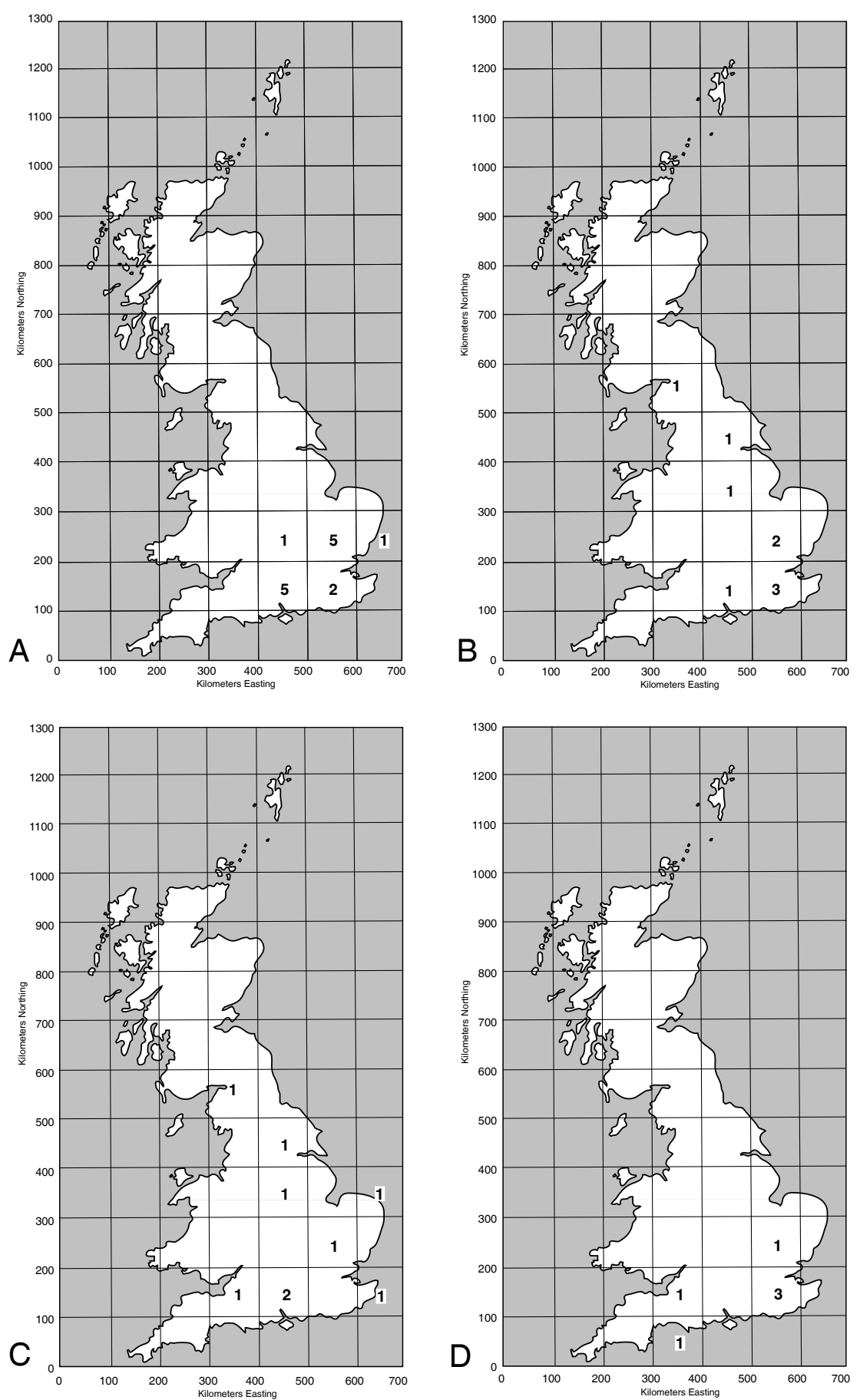

FIG. 7. Geographical distribution of records with archaeobotanical data from ceremonial sites, by phase of occupation. A. Early Roman; B. Middle Roman; C. Late Roman; D. Roman mid/late and undifferentiated. 

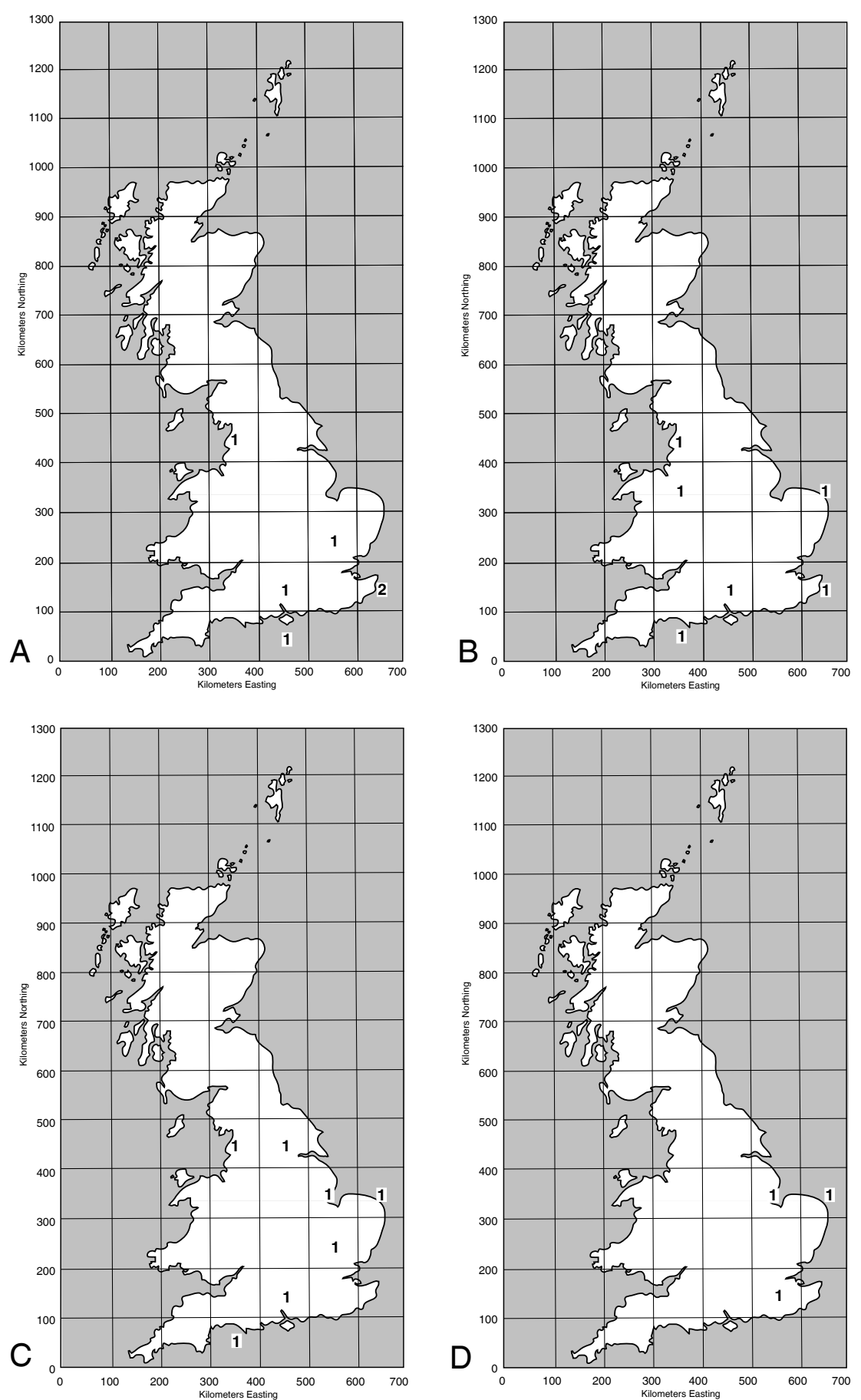

FIG. 8. Geographical distribution of records with archaeobotanical data from 'other' sites, i.e. industrial site, trading centre and shipwreck, by phase of occupation. A. Early Roman; B. Middle Roman; C. Late Roman; D. Roman mid/late and undifferentiated. 


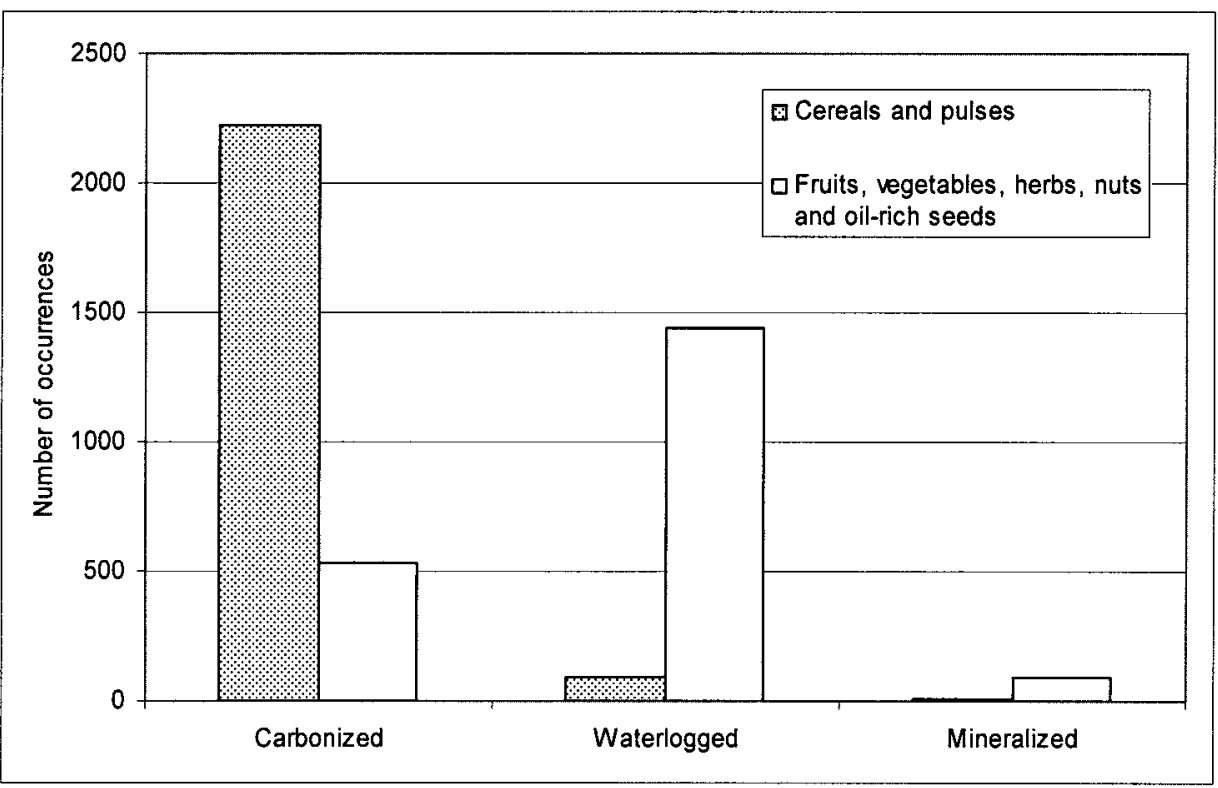

FIG. 9. Predominant mode of preservation for the two main food groups, based on the number of occurrences of each food plant in archaeobotanical reports from Roman Britain.

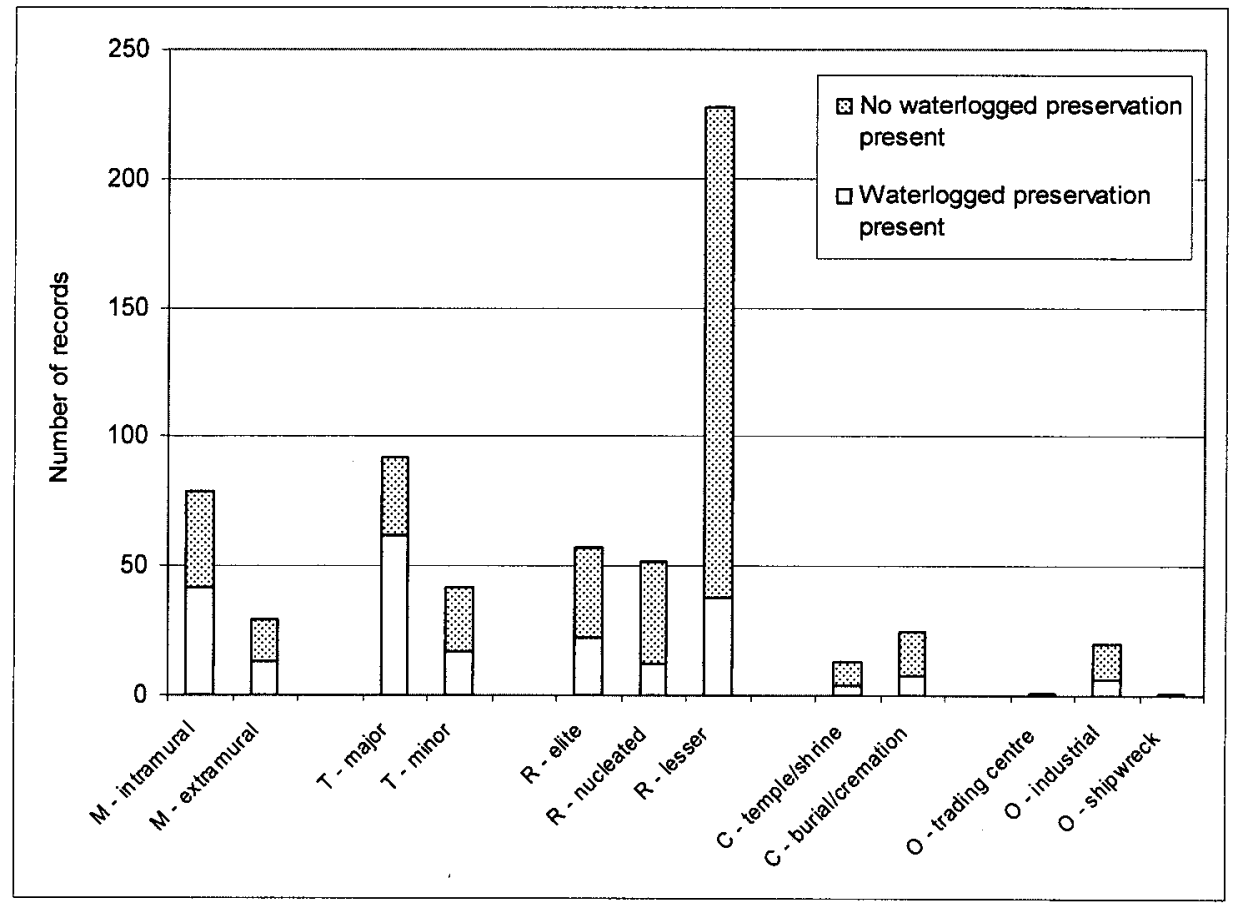

FIG. 10. Number of waterlogged records against the total number of records by site type. 
generally recovered in waterlogged contexts. Nuts take an intermediate position, as their shells are frequently recovered in charred assemblages. ${ }^{6}$

The implication of this is that if we want to reconstruct the arable regime of the period and/or the consumption of staples such as cereals and pulses, we need carbonized preservation, which is found on most settlement sites. Carbonized plant assemblages typically contain three main components: 'seeds' of the crops cultivated (wheat, barley, peas, beans, etc.), chaff (in the case of cereals), and weed seeds. The chaff is important for two reasons: it is usually more diagnostic than the grains themselves, thus enabling a more accurate identification of the cereal crops grown, and its presence or absence helps identify how and where the crop was processed after the harvest, and whether processing took place in small batches on a daily (or weekly) basis or in large quantities (family unit versus surplus production).$^{7}$ The arable weeds too are important, as their life form (annual/perennial) and ecology help identify the conditions in the arable fields, from which cultivation techniques (manuring, weeding, irrigation, etc.) and scales of production can be inferred. ${ }^{8}$

If we are interested in the consumption and cultivation of fruit, vegetables, herbs and oil-rich seeds, waterlogged records are the most informative. Waterlogged preservation is found when the water table is high, when wells or deep pits are present within the excavated area, or when deep stratigraphy is recovered. The latter often occurs on long-occupied settlements such as towns and some military sites, where the accumulation of organic-rich deposits creates a burial environment in which the anoxic conditions favour the preservation of plant material, even when full waterlogging is not present. Some fruits, vegetables and herbs are also found in mineralized form, usually in latrines, which are par excellence records of consumption, but in Roman Britain such contexts are (still?) very rare.

FIG. 10 shows the number of waterlogged records against the total number of records by site type. While about half the records from urban and military sites have waterlogged preservation, this figure drops to a fifth for rural sites (and just 17 per cent for rural lesser sites). As a result we have difficulty establishing with certainty the availability of foods such as fruits, vegetables, and herbs on rural sites, especially in regions of the country where few or no rural sites with waterlogged preservation are currently available (FIG. 11). The archaeobotanical sampling of rural sites with waterlogged preservation should thus be a research priority for the future.

\section{DATA QUALITY}

In order to create some measure of the data quality, an assessment was made of each report, taking into account: the number of samples analysed, the number of plant remains identified, the level of identification, whether the data were quantified (full two-way tables), whether the samples were well-dated, whether contextual information was present, and whether a full analysis of the data was carried out. The reports were graded as follows:

Good: dataset can be (has been) used to infer agriculture and/or diet, further analysis possible;

Satisfactory: dataset can be used to infer agriculture and/or diet, but is small;

Poor: dataset cannot be used to make reliable inferences regarding agriculture or diet, further analysis unlikely to be fruitful.

A fuller discussion will be presented in Van der Veen and Livarda in preparation.

Hillman 1981; Van der Veen 2007.

e.g. Van der Veen 1992; G. Jones et al. 1999, 2000. 


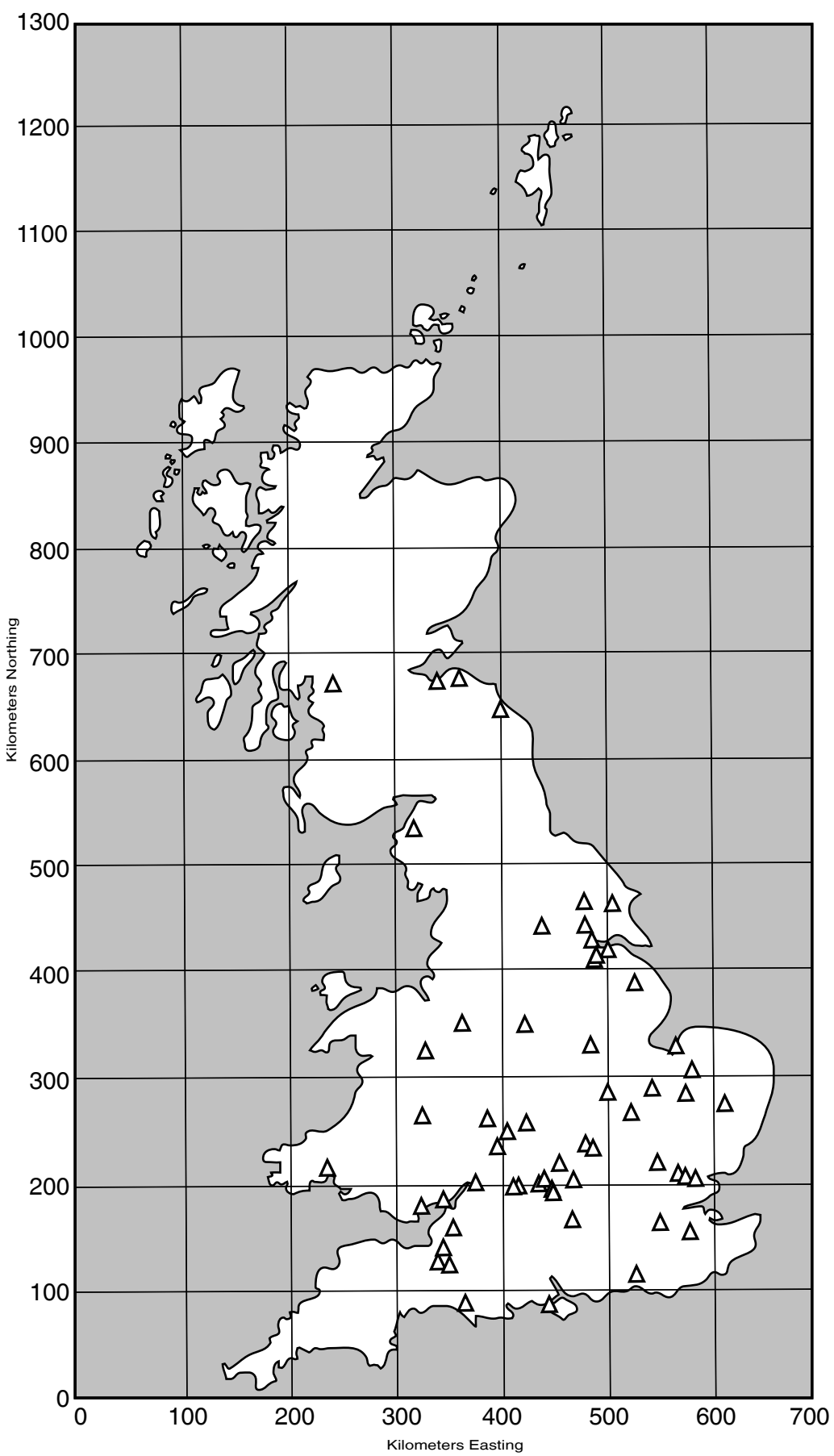

FIG. 11. Geographical distribution of rural sites with waterlogged preservation, all phases of occupation. 
Thus, reports graded 'poor' may be informative - for example the presence of pine cones (Pinus pinaea) at the Mithraeum at Carrawburgh near Hadrian's Wall ${ }^{9}$ - but are limited to the documentation of the presence of a particular species at a particular time and place. Reports graded 'good' deal with datasets that go beyond a 'species list' and can be (usually have been) used to reconstruct patterns of consumption or agricultural regimes. ${ }^{10}$ Table 3 gives the number of scores per category for each phase of occupation: only 15 per cent of records can be classified as 'good' and 44 per cent as either 'good' or 'satisfactory'. FIG. 12 shows the distribution of good quality datasets across site type and area of the country, and again highlights the presence of substantial gaps in the dataset currently available.

TABLE 3. NUMBER OF RECORDS WITH ARCHAEOBOTANICAL DATA BY PHASE OF OCCUPATION AND CLASSIFIED BY DATA QUALITY.

$\begin{array}{lrrrrrrr} & \text { ER } & \text { MR } & \text { LR } & \text { R m/l } & \text { R } & \text { Total } & \text { \% } \\ \text { Data quality } & & & & & & & \\ \text { Good } & 37 & 29 & 22 & 3 & 1 & \mathbf{9 2} & 15 \\ \text { Satisfactory } & 62 & 49 & 51 & 7 & 11 & \mathbf{1 8 0} & 29 \\ \text { Poor } & 113 & 79 & 102 & 11 & 39 & \mathbf{3 4 4} & 56 \\ \text { Total } & \mathbf{2 1 2} & \mathbf{1 5 7} & \mathbf{1 7 5} & \mathbf{2 1} & \mathbf{5 1} & \mathbf{6 1 6} & \end{array}$

\section{NUMBER OF SAMPLES}

This brings us to the number of samples analysed. Sample numbers are available for 577 out of 639 records. Clearly the collection and analysis of just a few samples is unlikely to provide information that is representative of all the people/plant activities occurring at a site. The number of samples may, of course, be low because the size of the excavation was small, but that still results in a dataset that is too small for detailed analysis. FIG. 13 presents histograms for the number of samples analysed per record (FIG. 13a), for each of the data quality classes (FIG. 13b, $\mathrm{c}$ and $\mathrm{d}$ ), and for each category of site separately (FIG. 13e, f, g and h). It is clear from FIG. 13 that datasets classified as 'good' are — not surprisingly — based on larger datasets, with those classified as 'satisfactory' or 'poor' based on much smaller numbers of samples. The fact that there are datasets classified as 'poor' that have 20 or more samples substantiates the fact that the quality classification is based on more than just the number of samples. In total, half of the records have just 1 to 5 samples, and only 135 records have datasets of 20 or more samples. This is a worrying state of affairs.

\section{DATE OF EXCAVATION}

The number of archaeobotanical publications and reports has risen steadily since the 1950s, with marked improvements in the 1970s and 1980s (the record for the 2000s is, of course, still incomplete). FIG. 14 gives the number of reports by date of excavation and FIG. 15 by date of publication. To assess whether the number of samples analysed has improved over the years, the mean and median number of samples have been calculated for each decade, and presented in FIG. 16. This shows that there was a steady increase from the 1950s onwards, but that from 1990 there has been a marked decline. This is also visible in FIG. 17, which shows the proportion of datasets

$9 \quad$ Blackburn 1951.

10 Published examples are: Charles et al. 1997; Davis 2000; Hall and Kenward 1990; Miller et al. 2000; Moffett et al. 1999; Murphy 2004; Probert 1997. 

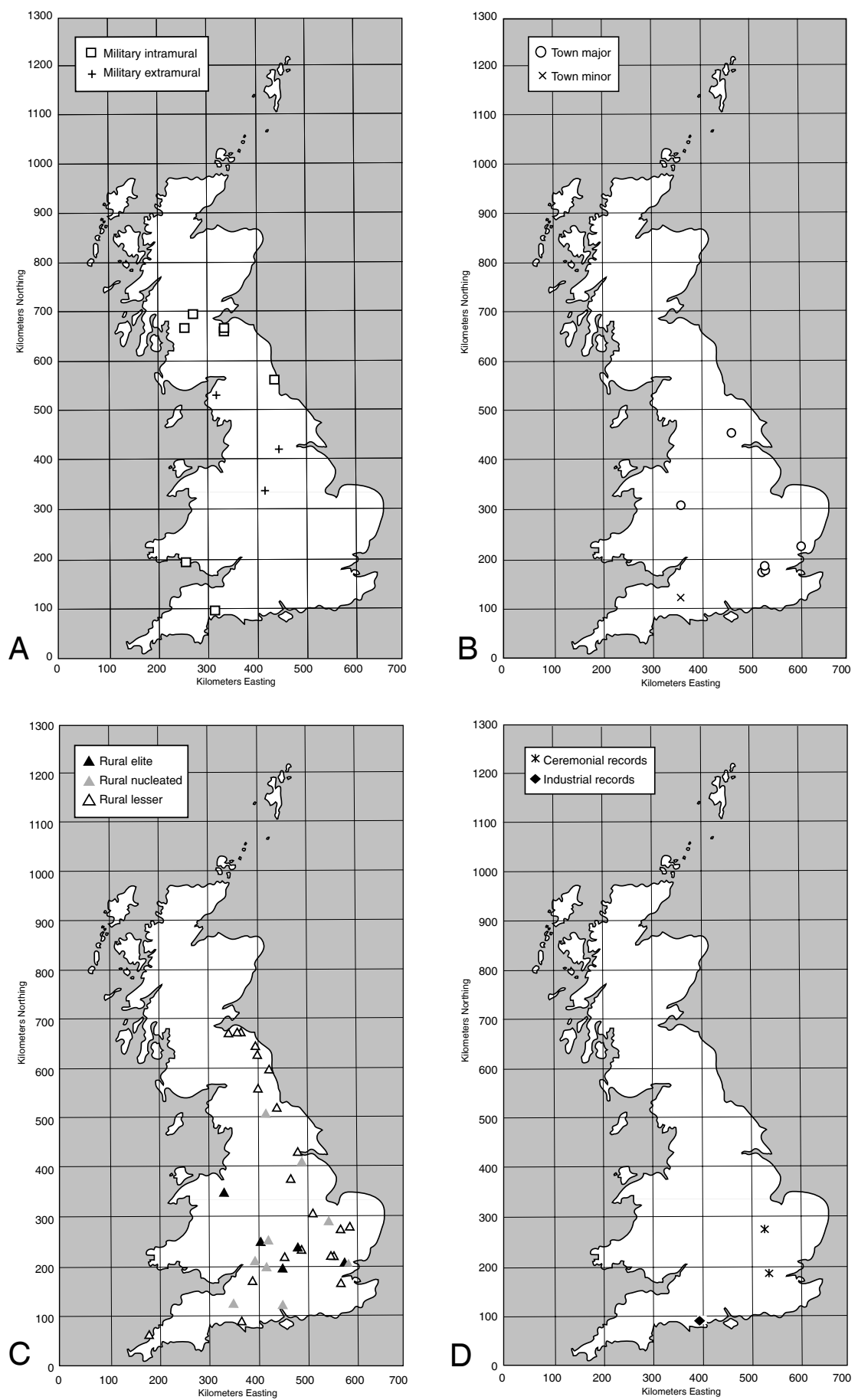

FIG. 12. Geographical distribution of good quality datasets, by site type. 


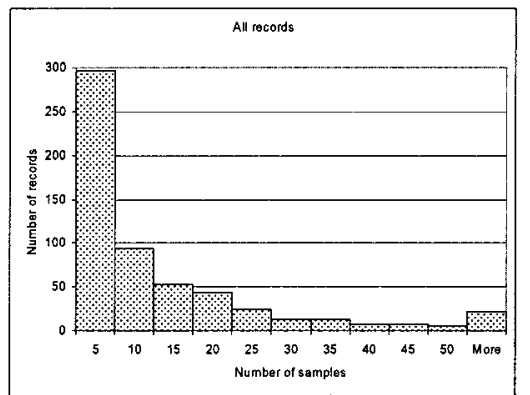

A.

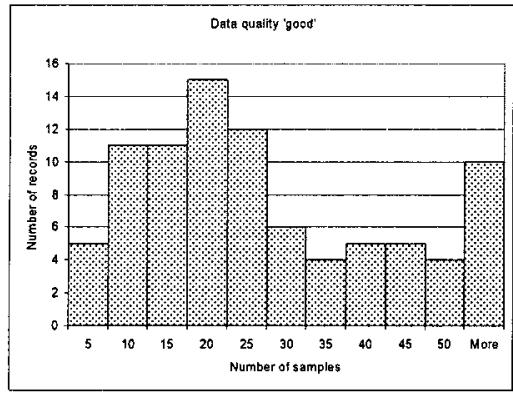

B.

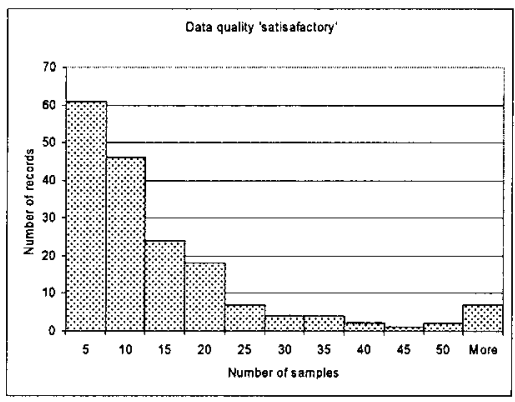

C.

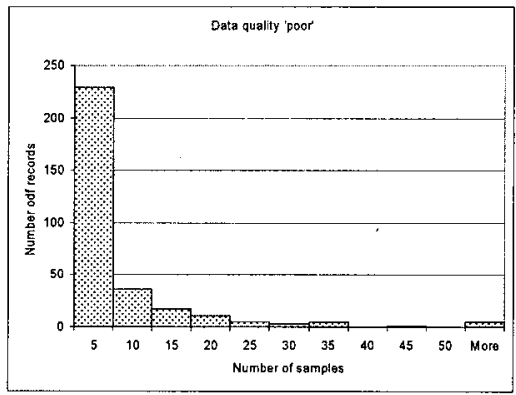

D.

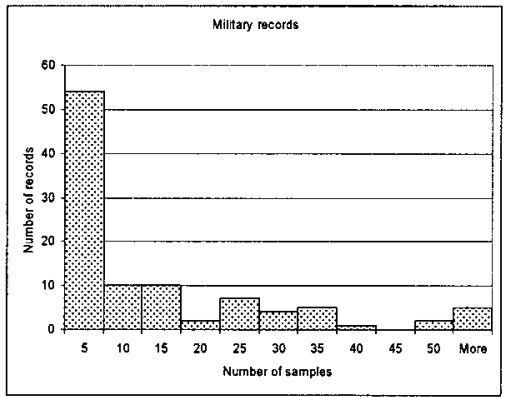

E.

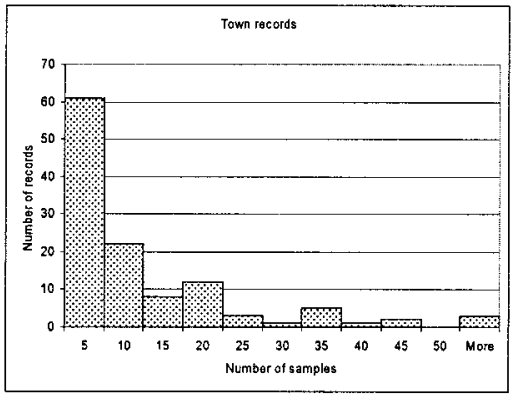

F.

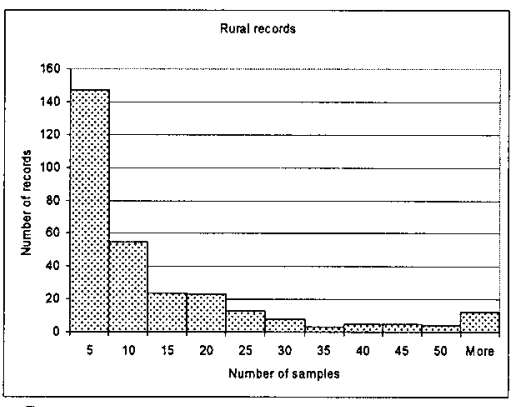

G.

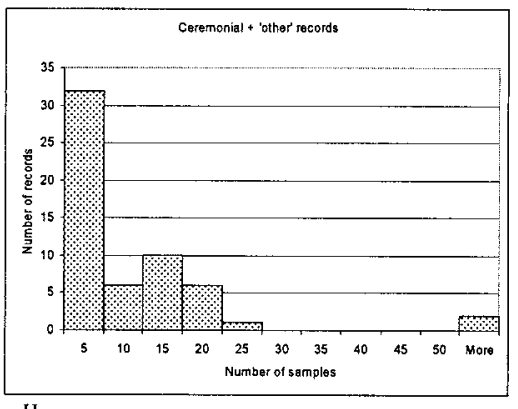

H.

FIG. 13. Number of samples analysed per record. A. all records; B. records with data quality 'good'; C. records with data quality 'satisfactory'; D. records with data quality 'poor'; E. records from military sites; F. records from towns; G. records from rural sites; $H$. records from ceremonial and 'other' sites. 


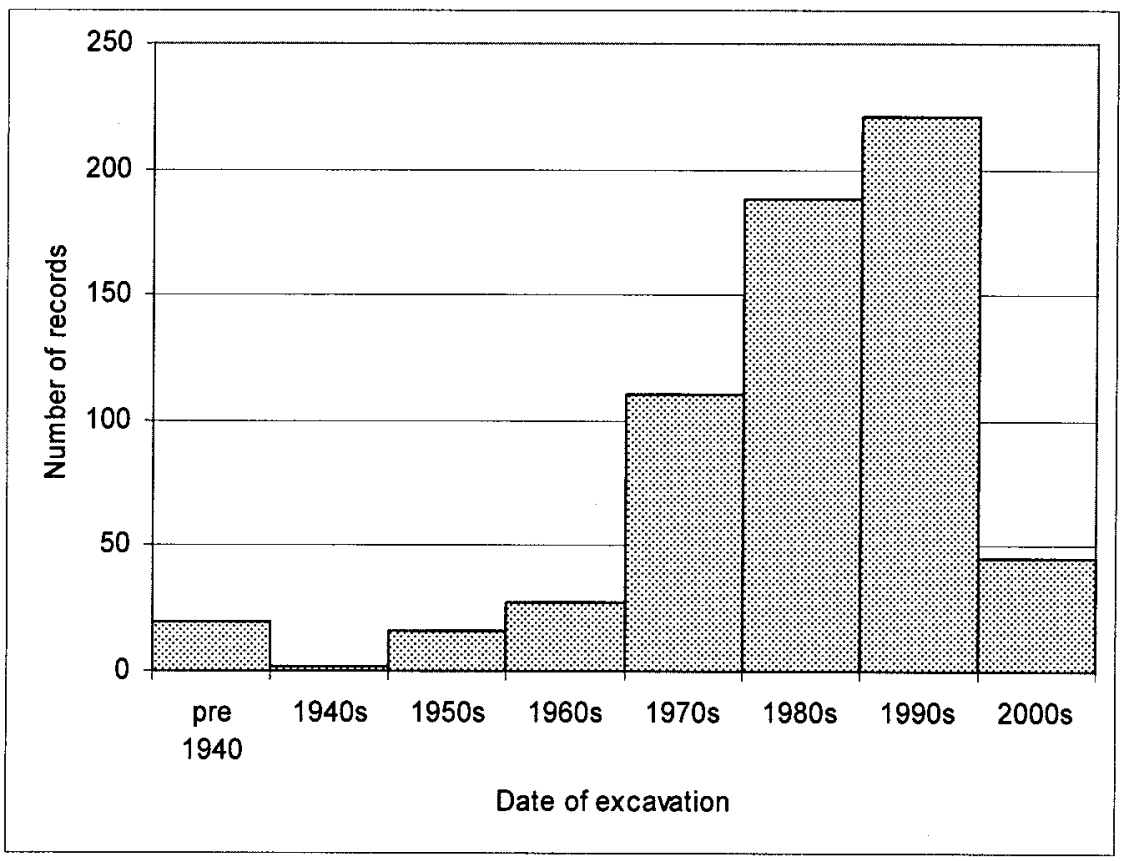

FIG. 14. Number of records with archaeobotanical data from Roman Britain, by date of excavation.

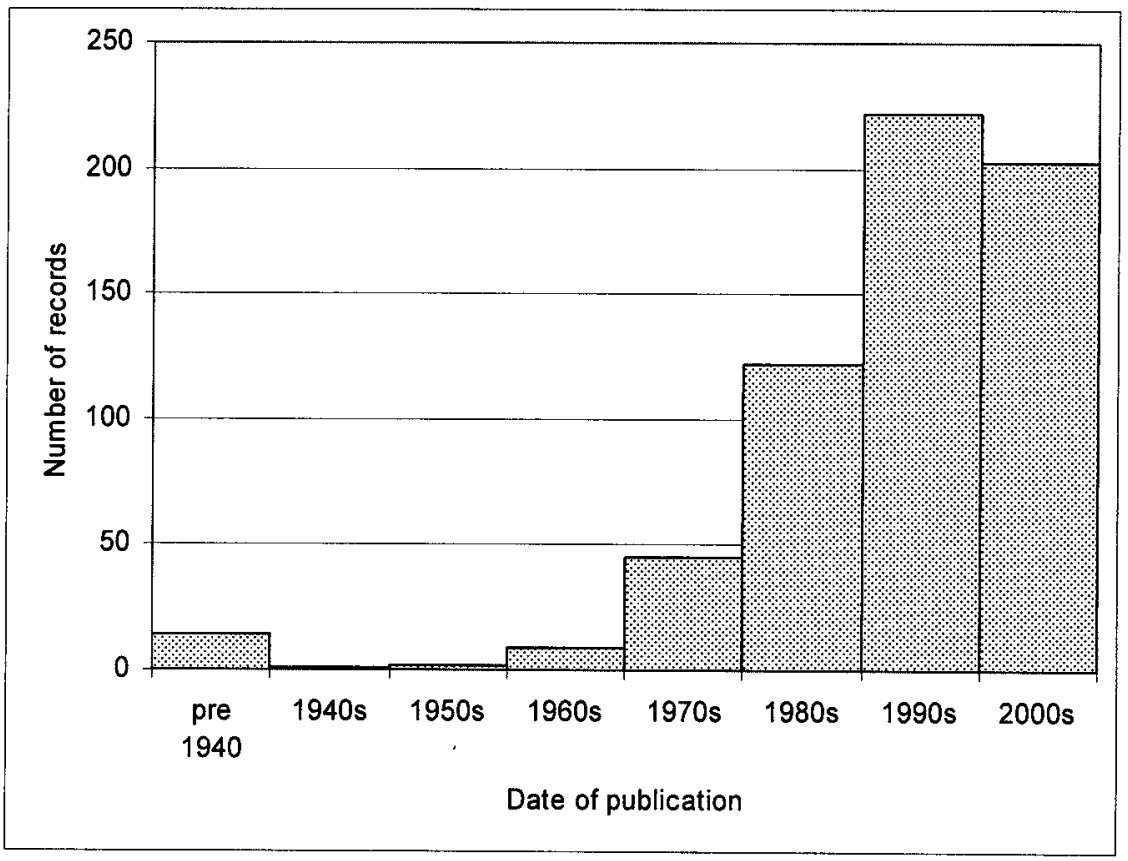

FIG. 15. Number of records with archaeobotanical data from Roman Britain, by date of publication. 


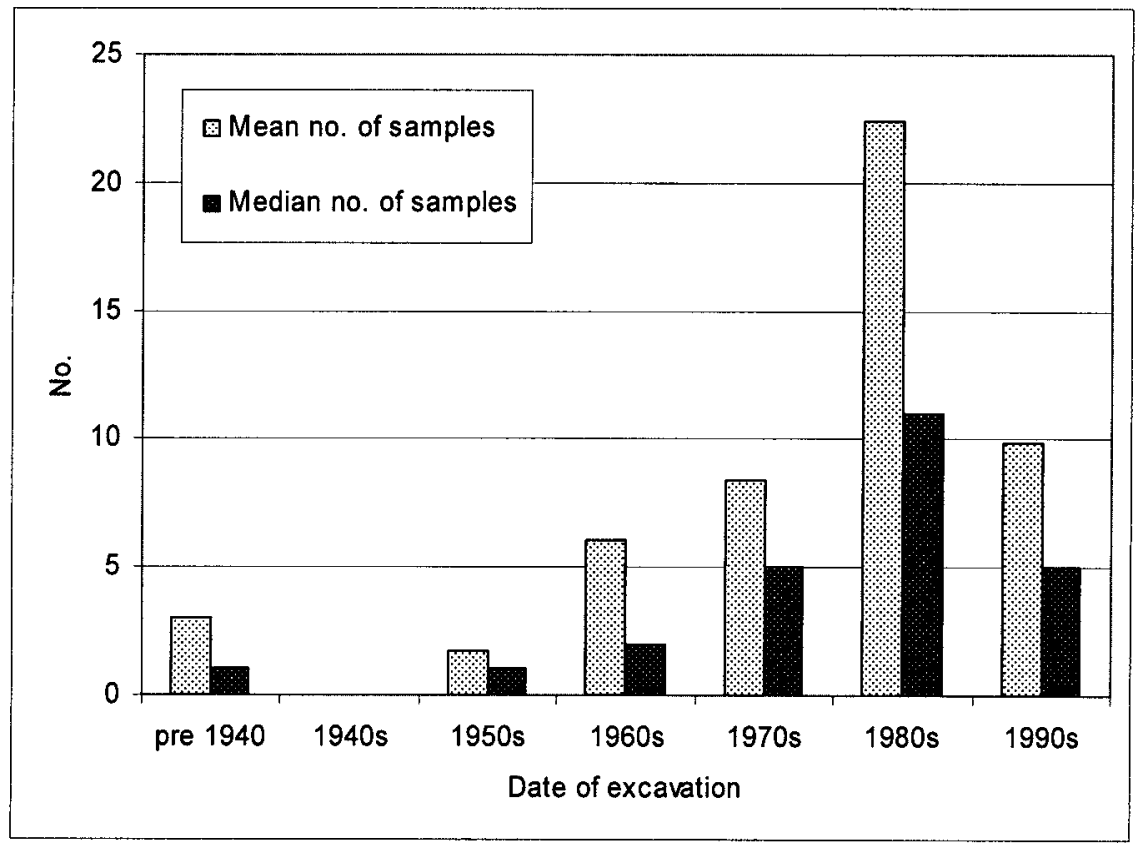

FIG. 16. Mean and median number of samples per record, by date of excavation.

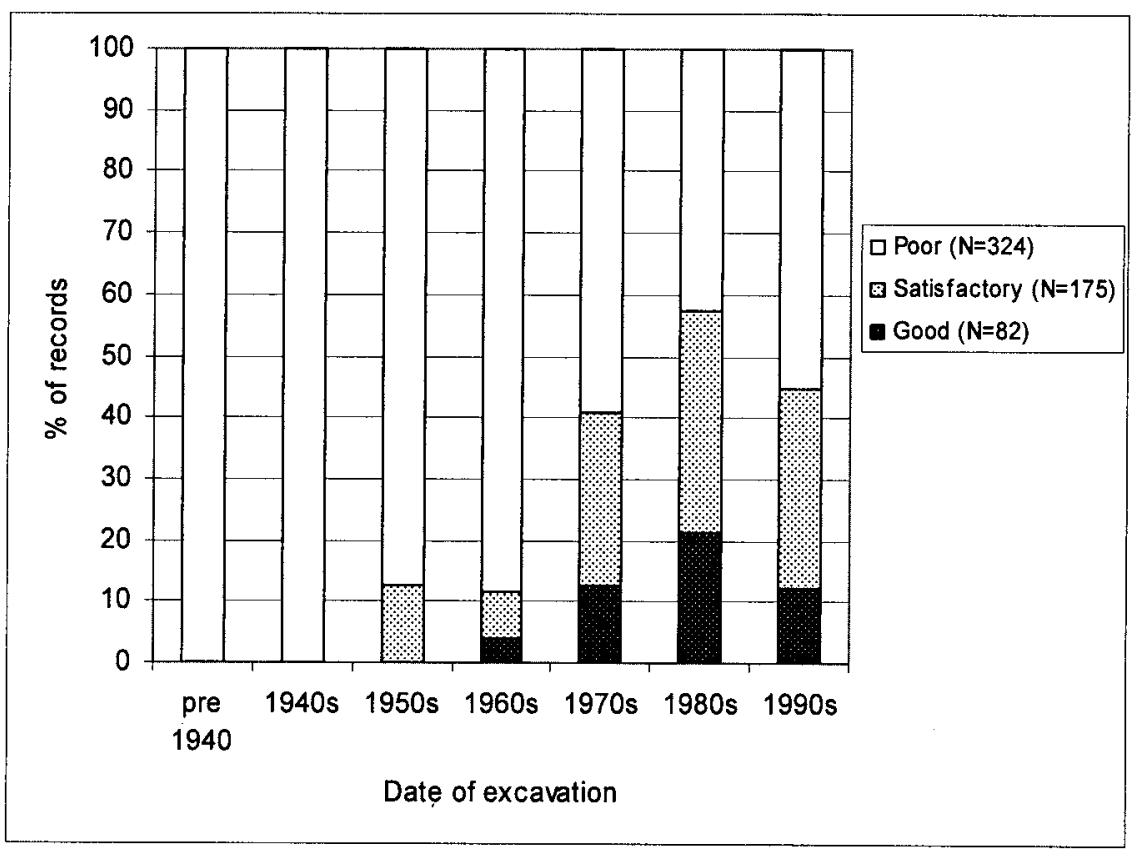

FIG. 17. Proportion of records with good, satisfactory, or poor data quality, by date of excavation. 
classified as 'good', 'satisfactory' and 'poor' by decade. Again, we see a gradual improvement from the 1950 s to the 1980 s, and then a marked reduction in data quality during the 1990s. (Data for the 2000s are not yet available due to the time-lag between excavation and report/publication availability.)

\section{MATTERS OF CONCERN}

During the data collection and analysis of the publications/reports for this review a number of issues came to our attention which are discussed here. While not specific to Roman Britain, they are relevant to our assessment of the state of the archaeobotany of Roman Britain.

\section{ACCESS TO PUBLICATIONS}

It has been difficult to obtain a full list of all archaeobotanical publications and reports for Roman Britain; the dataset used here is the best achievable in the timeframe available, but is certainly not complete. While the Environmental Archaeology Bibliography ${ }^{11}$ provides a listing, this list is not up-to-date, and has a coverage of so-called 'grey-literature' that is very patchy. Moreover, none of the 'Regional Reviews' for plant macro-fossils initiated by English Heritage ten years ago are published, and the information they contain is already starting to get out-of-date (personal communication from authors of these volumes). So when they are finally published they will not contain a full list of reports available. What is more, it is clear from the unpublished texts (several authors have kindly given us their draft texts) that each review takes a rather different format and contains different levels of detail.

\section{GREY LITERATURE}

Particularly problematic is the rapid increase in so-called 'grey literature'. This term is used to refer to reports that are not published, especially those arising from interventions undertaken since developer-funded archaeology became established in Britain; they thus increased in number very considerably after 1990 with the publication of the Planning Policy Guidance Note 16, Archaeology and Planning (PPG16), issued by the Department of the Environment in that year. In practice, the grey literature consists of two types of report: firstly, the unpublished reports that are part of a series. These reports have the series title and number, as well as an author, title, and date. Examples are the Ancient Monuments Laboratory (AML) reports (reports written by staff linked to the AML of English Heritage; now replaced by the Research Department Report Series), and similarly reports from MoLAS (Museum of London Archaeology Service), EAU (former Environmental Archaeology Unit, York), GUARD (Glasgow University Archaeological Research Division), DEAR (former Durham Environmental Archaeology Unit), ASUD (Archaeological Services University of Durham), etc. Secondly, there are unpublished reports, which are not part of a series, but simply reports commissioned by archaeological units or individuals. These are, generally speaking, not accessible for consultation. While a new Web-based database is now being constructed to contain unpublished reports on archaeological interventions (OASIS), it does not currently contain copies of so-called 'specialist reports'.

There are two problems with these reports: firstly, many are not refereed, and secondly, they are not always intended for publication and thus often lack vital data. For example, many such reports do not contain one or more of the following: exact location for the excavation from which 
the samples derive (no grid reference, county, or nearest settlement), classification of the type of site, dating evidence, context information, dating of each phase where samples are grouped by phase, number of samples, etc. The rationale for this is that the dating evidence and phasing were not available at the time of writing the report, and the presumption that such information will be available in the final publication. Many reports, however, may never be published, and copies circulated to interested parties thus lead a life independent of their archaeological context.

We have been very fortunate while conducting this review in that many authors of grey literature and unpublished reports have generously sent us copies, and provided additional information when asked, even when this meant they had to go back to the project director to obtain this information. We are also fortunate to work in the same department as two experts in the field, Jeremy Taylor and David Mattingly, whose detailed knowledge of Roman Britain meant that they could tell us the nature of the site where this information was missing from the report/publication. Without this help it would have been impossible to conduct this review. Where the grid reference was not given, we have had to take a best estimate.

\section{REPORT QUALITY}

There are too many publications and reports where the data are not placed in clear two-way tables with each column representing a sample and listing the context number, context type, sample volume, and dating evidence/phase. In some cases, we are told, this information is edited out of the report at the publication stage, to avoid duplication within the volume or to save on space. While such information may be held at the archive of the site, it is rarely feasible to collect such information from archives when a large number of sites is being studied, as for this synthesis. In our opinion it is essential that these core data are published with the archaeobotanical data.

\section{EXPERTISE}

The infrastructure for archaeobotanical work has changed dramatically over the last 50 years. In the early days the collection of archaeobotanical data was often haphazard and material visible with the naked eye was collected and given to a friendly botanist who would carry out the identifications and present a list. Over time Britain came to stand at the forefront of archaeobotanical (and archaeozoological work) with the creation of regional laboratories funded first by the Department of the Environment and later by English Heritage. (There was some parallel support for archaeobotany in Wales by CADW and in Scotland by Historic Scotland, though laboratories on the scale of those funded by English Heritage have never been achieved in these two parts of Britain.) The EH-funded laboratories were mostly attached to universities and staff had the benefit of being part of a research structure with facilities for keeping up-todate with new developments in the field, with colleagues at hand to help check the work, and the possibility of further training. Today, these laboratories no longer exist and many of the people who now write the archaeobotanical reports are working free-lance without regular access to a full reference collection (essential for accurate identifications), laboratory facilities, library, and colleagues who can provide assistance, or quality control. The current situation is detrimental for the individuals concerned and for the discipline. Kenward and Hall express a similar view. ${ }^{12}$

As highlighted above, the range of cultivated and wild plants encountered in the samples is heavily dependent on the mode of preservation and type of site sampled. Many archaeobotanists will, over time, tend to develop expertise in the identification and interpretation of either carbonized or waterlogged specimens. As some plant species are very difficult to identify, especially when 
poorly preserved or fragmented, help from colleagues is often necessary (the first author herself has frequently needed the assistance of colleagues to ensure accurate identifications). Moreover, rare and exotic species may not be recognized by inexperienced colleagues or those normally working with just one mode of preservation. Working as part of a team can help avoid mistakes in identification. Working in isolation, from the 'kitchen-sink' so to speak, is asking for trouble.

That such mistakes can be quite significant is illustrated by an example from Roman Bath. Both Davenport and Durrani ${ }^{13}$ published the find of black pepper (an import from India) at recent excavations there. As such finds are extremely rare (so far black pepper has only been found in Roman London), it received considerable attention. It is now clear, however, that this identification is incorrect (R. Pelling pers. comm.). Here it was not the lack of quality control, but the fact that the find was published before the quality control had been implemented!

\section{ASSESSMENTS AND RECOMMENDATIONS FOR FURTHER WORK}

As demonstrated above, there has been a dramatic decline in the number of samples analysed during the 1990s. This would seem to be directly linked to the rise of developer-funded archaeology and the implementation of the guidelines incorporated in PPG16. The result has been an increase in small-scale evaluations (plus the demise of large research excavations), and the collection of small numbers of samples from (often) poorly-understood archaeological contexts. Samples collected from those projects where further excavation does take place are 'assessed' and frequently only a few 'rich' samples are fully analysed and reported on. This practice is laid down in Environmental Archaeology ${ }^{14}$ To be fair, this document does not specifically recommend that only 'rich' samples should be analysed; the exact wording is: 'An assessment should give consideration to the potential contribution the material could make to archaeological knowledge ... and make recommendations for the type and scope of further analysis ... To be cost-effective these decisions should be made in the light of best academic knowledge, and therefore need to be carried out by specialist staff who are highly experienced in studying the type of material being assessed' (emphasis by the authors). In practice, these assessments are made by a variety of individuals, experienced and inexperienced, and recommendations for further work tend to focus on the samples rich in plant remains. Apart from the fact that there is no definition of what constitutes a 'rich' sample, negative evidence is important too, if we are to understand the variation of people/plant activities and their location within the settlement. While assessments should summarize all the evidence recovered, including the negative evidence, this is not always happening, at least not in enough detail. Moreover, the tendency to analyse a few rich samples often results in a bias towards certain feature types, such as the so-called corn-driers. These frequently yield deposits with a high density of plant remains. While such samples are important, they inform about one activity only, and crops not processed in these structures are consequently not recovered. This can lead to spurious conclusions regarding the importance of one cereal crop over another. ${ }^{15}$

\section{RESEARCH PRIORITIES}

This review has identified a number of lacunae in our current knowledge. Here these are identified in the hope that some may be redressed in the near future.

13 Davenport 2004; Durrani 2004.

14 English Heritage 2002, 24.

15 Van der Veen research in progress. 


\section{GENERAL}

The dataset is now large enough to inform us on the basics (which crops were grown, which foods eaten). Future data collection should concentrate on filling specific lacunae in the dataset and addressing specific research questions. The latter requires high-quality datasets and this has implications for sample size, choice of site, numbers of samples to be collected, etc.

For statistical analyses we ideally use samples with at least 100 identified specimens (though preferably larger, i.e. between 300 and 500) ( $^{16}$ per mode of preservation (i.e. 100 carbonized or 100 waterlogged, not 30 of one and 70 of the other), and sample size at collection stage needs to be adjusted to ensure this. Thus, rather than routinely collect 5 or 10 litres of sediment, the size of the sample needs to be proportional to the likely density of the remains within the deposits (and mode of preservation); this can be achieved by carrying out some early assessment of the deposits. In many cases a sample size of 40-60 litres will be needed for carbonized plant remains. (Where a 60-litre sample does not produce $c$. 100 specimens it is rarely worth collecting more.)

It is much more difficult to give a guideline for the number of samples needed, as this depends on the questions asked. For example, a comparison between different feature types or between different parts of the settlement requires there to be enough samples from each subgroup (e.g. pits, ditches, post-holes or Area A, B and C) to be statistically meaningful. When we add further variables such as phase of occupation and processing stage of the crop (grain or chaff/weed rich) it becomes clear that the number needed is very high indeed. For example, while 30 samples per record (i.e. per phase of occupation/type of site) may seem a large number, we will only be able to determine type of cultivation regime if most of them are rich in weeds.

Thus, the ideal number of samples is often very high, and may not always be achievable. A very rough guide would be a minimum of $c .30$ samples with usable information per record (i.e. per phase of occupation/type of site), though more is always better in this case, especially on large sites. Best practice would be to sample all closely-dated and well-sealed deposits and all feature types, and collect multiple samples from large features. Datasets with fewer than 10 samples become problematic in the case of carbonized assemblages, except in regions where little is known to date, or where group-value comes into play (i.e. where small numbers of samples may become available from each one of multiple interventions at the same site). Smaller datasets might, however, still be very informative in the case of waterlogged and mineralized assemblages.

This last point raises the issue of preservation. It is important to remember that carbonized, waterlogged, and mineralized assemblages in most instances provide different types of information. Carbonized assemblages are most informative on the staple crops cultivated (cereals, pulses, fibre and fodder crops), the cultivation regime, and arable strategy, as well as fuel use. Waterlogged assemblages are more informative on foods such as fruits, herbs, and vegetables, and also contain information on the type of vegetation growing in the immediate environment of the sample location, as well as the use of medicinal plants, dye plants, and decorative plants in gardens. Mineralized assemblages are in most instances records of consumption; they usually originate from cesspits, latrines and the like, and contain stones and pips of fruits consumed.

To summarize, in order to answer the wider research questions the priority is to:

- Collect larger datasets, consisting of samples from all closely-dated contexts;

- Collect samples which will yield at least 100 identifications and preferably considerably more; this means increasing the sample size to get the required amount and testing for 
density of plant remains in the deposits at every new site at the start of the excavation; sample volumes of 40-60 litres are often essential for carbonized data and c. 10 litres for waterlogged data; (where samples are used for the recovery of small bones and other finds as well as plant macro-fossils, sample sizes often need to be much larger still);

- Select sites where large-scale sampling is to be carried out - if necessary at the cost of not sampling each site; for example, select sites that are expected to be excavated in their entirety, or where the majority or a good range of context types are expected to be excavated;

- $\quad$ Adopt separate sampling strategies for carbonized and waterlogged deposits;

- $\quad$ Record and publish samples with negative and negligible as well as positive results together with their archaeological dating, context, and location.

\section{AGRICULTURE}

The current dataset is such that we broadly know which crops were cultivated in Roman Britain, but this review has identified a number of regions where our knowledge is still very limited indeed (FIGS 3-8). Moreover, we have as yet little detailed information on the type of cultivation practised (e.g. small- versus large-scale cultivation, expansion of cultivation, switch to new crops, practice of autumn- and/or spring-sowing, manuring, weeding). Reconstructions of such practices require large numbers of samples from well-dated sites with enough identifications to carry out detailed statistical analyses on data concerning the arable weeds. A further question that cannot be adequately addressed at the moment is that of the impact (positive or negative) of the sustained military presence on the rural economy in the military zone. Again, this requires large-scale sampling on rural settlements in this zone, and especially in areas close to military sites. To summarize, in terms of agriculture the priorities are to:

- $\quad$ Collect carbonized plant remains from South-West and North-West England, Wales and Scotland. In fact, from these regions even sites with just a few samples are worth having, though larger datasets must be a priority;

- Collect carbonized plant remains from rural settlements in the military zone and especially from areas close to military sites;

- Select a series of rural settlements for detailed, large-scale archaeobotanical sampling, in order to collect enough samples with sufficient identifications to allow detailed statistical analyses of the arable weed flora, with the purpose of reconstructing cultivation regime and arable strategy;

- Collect samples from all granaries, barns, and aisled halls, and from other forms of storage (pits, vessels, etc.), to establish which crops are stored in them, at what stage in the processing sequence, and at what type of sites grain and other crop seed is stored in large quantities. ${ }^{17}$

\section{HORTICULTURE}

The cultivation of fruit trees (apple, pear, cherry, plum, damson), nut trees (walnut), herbs (coriander, fennel, dill, summer savory, etc.), and vegetables (turnip, cabbage, carrot, leek, etc.) differs from that of the staples such as cereals in that it takes place in gardens or orchards (hortus

\footnotetext{
17 Moreover, storage contexts with low oxygen content may slow down DNA degradation in grains and seeds; seeds from such contexts may thus possess an improved chance of DNA preservation: Threadgold and Brown 2003.
} 
= garden), rather than fields. These food plants require intensive cultivation, including manuring, and, in the case of herbs and vegetables, regular weeding. For these reasons such 'gardens' are usually located close to the house. ${ }^{18}$ Moreover, as their produce is mostly perishable and cannot be stored for long periods of time prior to our modern methods of refrigeration, and because most produce is ripe at the same time, such cultivation tends to take place in regions and societies where there is a ready 'market', i.e. where there is a demand for such produce. Thus, most horticulture takes place close to towns or other centres with large numbers of consumers. A review of the evidence for Roman Britain ${ }^{19}$ shows that all the evidence for horticulture currently available is located in South-East Britain. This is, of course, the region where most Roman towns are found, but it is also the region where most archaeobotanical work has taken place. Currently we have virtually no rural records with waterlogged preservation from Northern and Western England, Wales, and Scotland (FIG. 11), making it impossible to detect evidence for horticulture here. The military did, of course, represent the other large consumer group $;{ }^{20}$ it acquired its food partly through requisitioning or taxation, and partly through purchase. The latter may have acted as an incentive for innovation of production and could thus have encouraged the establishment of horticulture.

Another aspect concerns the establishment of horticulture in Britain. Was it the concept of horticulture that was introduced or were actual cultivars (and rootstock in the case of the fruit trees) brought to this country? For example, recent DNA analysis of domestic apple (Malus domestica) has indicated that, contrary to what was previously thought, its wild progenitor is not Malus sylvestris, the native British crab apple, but Malus sieversii, native to the mountains of Kyrgyzstan and North-West China. ${ }^{21}$ This implies that a new, cultivated species of apple was introduced into Britain. It would thus be worthwhile analysing Iron Age and Roman apple pips to test whether their DNA is preserved. If the Romans introduced cultivated apples, as we believe, we should see a clear shift from one species to another over time. ${ }^{22}$

To summarize, in terms of horticulture the priorities are to:

- Collect waterlogged assemblages from rural sites for all parts of the country, but especially from South-Western and North-Western England, Wales, and Scotland, to establish when horticulture became established here;

- Collect waterlogged assemblages from rural settlements in easy reach of military sites, to establish whether they may have supplied the military with horticultural produce;

- Conduct ancient DNA analyses on fruits and vegetables to determine exact botanical species and geographical area of origin; apple would be a good starting point.

\section{IMPORTED FOODS}

While current evidence suggests that the importation of new foods from the Mediterranean region (e.g. figs, grapes, olives, various herbs, etc.) was a Roman phenomenon, the validity of this suggestion cannot be assessed fully without good archaeobotanical data from Late Iron Age sites with waterlogged preservation. Samples yielding such data are urgently needed from South-

G. Jones 2005; Van der Veen 2005.

Van der Veen et al. in press.

Not dissimilar in size to the urban population: Mattingly 2006, 356; Millett 1992, 182.

1 Harris et al. 2002.

22 Such analyses are still in their infancy, but for some first examples see Elbaum et al. (2006) for olive; Manen et al. (2003) for grape; Pollmann (2005) for plums; see also Cooper and Poinar (2000) and Yang and Watt (2005) for methodologies and procedures. 
East England, the region in which the earliest imports (wine amphorae and other ceramics) have been recorded. The priority thus is to:

- Collect waterlogged samples from Late Iron Age settlements in South-East England in order to test for the presence of foods imported from the Mediterranean region.

\section{SOCIAL ACCESS TO FOOD}

Food is fuel for the body and the soul. The fact that we prepare and cook our food makes us human, while what we eat and the way we prepare it helps define our cultural identity. Moreover, we use food and drink to construct our social relationships, ranging from the maintenance of family bonds (through family celebrations of major rites of passage and religious festivals) to the creation of social status within the wider society (through hosting feasts for dependants or through conspicuous consumption with those of equal or higher status). Archaeobotany can contribute to the study of social diversity and distinction by establishing differences in social access to certain types of foods. Access to imported foods or newly-introduced foods, both of which are likely to have been expensive or difficult to obtain, can be used as an indicator of social and economic wealth. ${ }^{23}$ Most of these foods (imports such as black pepper, fig, grape, olive, date, sesame, cucumber, and introductions such as apple, pear, cherry, walnut, etc.) are found in waterlogged plant assemblages (FIG. 9) and samples from waterlogged deposits are needed from all types of site (as already indicated above). Apart from the dearth of waterlogged assemblages from rural sites, we urgently need more data from major town sites. Currently, London stands out, not only in terms of the number of archaeobotanical reports available (Table 2 ), but also in terms of the range of imported foods recovered there. ${ }^{24}$ While we can identify differences between sites (broad social groups) on the basis of current evidence, ${ }^{25}$ only London has what can be considered an adequate amount of data to study social access within a town. There are, in fact, reasons to view London as somewhat atypical of Romano-British towns. ${ }^{26}$ The priority is thus to:

- Collect more waterlogged data from rural settlements, in order to assess the extent to which such settlements had access to imported and newly-introduced foods;

- Collect more archaeobotanical data from the major towns other than London, to facilitate assessment of the uniqueness of London in terms of access to imported foods, and to obtain data for studies of social access within urban communities.

\section{FOOD IN RITUAL AND RELIGION}

Food also plays a role in ritual and religious practices. In many societies the placement of food with the dead, the consumption of food during the burial ritual, and the votive offering of foods at temples and shrines was commonplace. Patterning in the type of foods used for these occasions can help identify social as well as cultural diversity. ${ }^{27}$ In Britain such studies are still rare and sampling of both burials and temple/shrine sites is desirable. The priority is thus to:

Bakels and Jacomet 2003; Mattingly 2006, 474-6; Van der Veen 2003; Van der Veen et al. in press.

Van der Veen et al. in press.

Van der Veen et al. in press.

Mattingly 2006, 273-5; Millett 1992, 88-91.

27 Examples of archaeobotanical studies of food associated with burials (cremations and inhumations) are published by Bouby and Marinval 2004; Davis 2000; Kreuz 2000; Petrucci-Bavaud and Jacomet 1997; and PetrucciBavaud et al. 2000, while examples of archaeobotanical evidence for votive offerings are published by Robinson 2002 and Zach 2002. 
- Collect archaeobotanical samples from burials (cremations and inhumations) and temples/ shrines to determine which foods were favoured in these ritual contexts, as well as charcoal samples for analysis of fuel use.

\section{CONCLUSION}

The archaeobotanical dataset from Britain in the Roman period is quite substantial, ${ }^{28}$ and is starting to produce country-wide patterning in the dispersal of new foods introduced during this time, the establishment of horticulture, and variations in agricultural production. ${ }^{29}$ Yet, despite the large number of records available, several major lacunae have been identified. The geographical coverage of the dataset is poor, with most data originating from sites in the CentralSouthern and South-Eastern parts of the country. Whilst there is a reasonably good spread across the Early, Middle and Late Roman periods, and across the different types of site, small rural sites are under-represented considering that these denote the largest group of settlements at each time. Some worrying trends have been observed: the number of samples analysed per record, while increasing steadily since the $1950 \mathrm{~s}$, has started to decline considerably during the 1990s, probably in connection with the growth of developer-funded archaeology and PPG16. Related to this is the increase in unpublished reports (grey literature) in which the archaeobotanical data are described without adequate reference to their archaeological context. The research value of reports based on just a few samples from small-scale interventions has been questioned.

In terms of future research on the agricultural systems of Roman Britain, we need to collect more (carbonized) data from the Northern and Western parts of the country. While in SouthWestern England, North-Western England, Wales, and Scotland the current coverage is so poor that even single samples are better than nothing, the aim should be to collect larger datasets. Here group-value is also important; i.e. small numbers of samples from a range of similar sites, or from a series of interventions on the same site, can help build up a first picture. For CentralSouthern and South-Eastern England the ideal target must be large-scale excavation of rural settlements with archaeobotanical samples collected from all closely-dated deposits and feature types. Where funding is tied to individual projects, strategies need to be designed to make these larger archaeobotanical datasets a reality.

In terms of future research into the establishment of horticulture and social access to the new foods, more samples must come from waterlogged deposits. Such samples are needed from the major towns, and from all rural sites, especially those in the northern and western parts of the country and those located in the vicinity of the military sites. They are also required from Late Iron Age sites in South-East England to establish when these foods were first introduced. Assessment of the presence of DNA in charred and waterlogged seeds of the new horticultural plants (apple, pear, cherry, plum, cabbage, turnip, leaf beet, etc.) and the subsequent analysis of that DNA will, in the longer term, help us to understand how these new foods arrived in this country and from where they originated.

The collection of archaeobotanical data from burials and temple/shrine sites should become routine practice. Such data might well help identify cultural and religious differences between the various population groups of Roman Britain, and in the case of burials can distinguish practices between individuals and/or their families.

In terms of data reporting, both positive and negative evidence should be reported in full, with context number, sample volume, mode of preservation, type of context, phase of occupation, 
area of the site, type of site, grid reference, and dating evidence given for each sample assessed/ analysed. The location of the reports on the excavation and other archaeological data from the same site should be clearly indicated. Where traditional publication is unlikely to occur soon, such reports need to be published on the Web, either within OASIS or a similar database. A mechanism needs to be established for ensuring that any subsequent changes in the data (reidentification, changes in the phasing of a context) are clearly flagged in such web-based publications, as well as in the subsequent publication of the data in a journal or monograph.

It is clear that much valuable archaeobotanical data have been gathered during the last 50 years or more. To build on this and reverse the recent trend towards poorer quality datasets, it is essential that the current piecemeal approach to archaeobotanical data collection is overturned; such an approach to the data is detrimental for the discipline of archaeobotany and for the wider academic value of the data. What are needed are larger datasets and a more regional approach to data collection, which can only be achieved by increased collaboration between archaeological units, county and district archaeologists, academics and specialists, as well as by a pro-active role from the English Heritage regional scientific advisors, and the heritage bodies (English Heritage, CADW and Historic Scotland). The archaeological and historical narrative for Roman Britain can only be enhanced through more joined-up thinking by all involved.

\section{ACKNOWLEDGEMENTS}

This project could not have been completed without the help of very many institutions and individuals. M. van der Veen would like to thank the University of Leicester and the Arts and Humanities Research Council for the research leave during which this project was completed, the British Academy for a grant that funded the bibliographical searches and part of the data collection by Alistair Hill, and the Natural Environment Research Council for a large research grant that part-funds Alexandra Livarda who completed a large part of the data recording and constructed the database. A. Livarda is grateful for the scholarships from the Leventis Foundation and the Onassis Foundation. We are grateful to Neil Christie, Simon James, and especially David Mattingly and Jeremy Taylor for their assistance with the site classifications, phasing, and information about particular sites. Dimitris Kourkoulis, Alex Moseley, and Niven Moledina kindly gave their time to help with the construction of the Access database. Many colleagues have helped by generously sending references, copies of grey literature and/or their unpublished data: Paul Booth, Gill Campbell, Wendy Carruthers, Astrid Caseldine, Mike Charles, Marina Ciaraldi, John Giorgi, James Greig, Allan Hall, Tim Holden, Jacqui Huntley, Jennifer Miller, Lisa Moffett, Angela Monckton, Peter Murphy, Ruth Pelling, Mark Robinson, Vanessa Straker, and Scott Timpany, while Alison Cox and Jacob Morales helped with the acquisition of the reports. We are grateful to Catherine Johns who brought the mistaken identity of the black pepper from Bath to our attention. FIGS 3-7, 11 and 12 were drawn up by Debbie Miles-Williams. We are very grateful to Gill Campbell, Allan Hall, David Mattingly, and Jeremy Taylor for helpful comments on an earlier draft.

\section{School of Archaeology \& Ancient History, University of Leicester \\ mvdv1@leicester.ac.uk}

\section{BIBLIOGRAPHY}

Bakels, C., and Jacomet, S. 2003: 'Access to luxury foods in Central Europe during the Roman period: the archaeobotanical evidence', World Archaeology 34(3), 542-57

Blackburn, K. 1951: 'Appendix I. Report upon the natural pine-cones from the temple of Mithras at Carrawburgh', in I.A. Richmond and J.P. Gillam, 'The temple of Mithras at Carrawburgh', Arch. Ael. ${ }^{4}$ 29, 1-92 (at 86)

Bouby, L., and Marinval, P. 2004: 'Fruits and seeds from Roman cremations in Limagne (Massif Central) and the spatial variability of plant offerings in France', Journal of Archaeological Science 31(1), 77-86 
Charles, M., Colledge, S., and Monk, M. 1997: 'Appendix 6: plant remains', in P. Barker, R. White, K. Pretty, H. Bird and M. Corbishley, The Baths Basilica, Wroxeter. Excavations 1966-1990, English Heritage Archaeological Report 8, London, 324-49

Cooper, A., and Poinar, H.N. 2000: 'Ancient DNA: do it right or not at all', Science 289, 113

Davenport, P. 2004: 'Exotic food remains from Roman Bath', Salon, The Society of Antiquaries of London Online Newsletter 104

Davis, A. (with de Moulins, D.) 2000: 'The plant remains', in B. Barber and B. Bowsher (eds), The Eastern Cemetery of Roman London; Excavations 1983-90, MoLAS Monograph 4, London, 69-71 and 368-78

Durrani, N. 2004: 'Luxury Bath', Current Archaeology 195, 105

Elbaum, R., Melamed-Bessudo, C., Boaretto, E., Galili, E., Lev-Yadum, S., Levy, A.A., and Weiner, S. 2006: 'Ancient olive DNA in pits: preservation, amplification and sequence analysis', Journal of Archaeological Science 33, 77-88

English Heritage 2002: Environmental Archaeology: A Guide to the Theory and Practice of Methods, from Sampling and Recovery to Post-Excavation, English Heritage, Centre for Archaeology Guidelines 2002/01, Swindon

Greig, J.R.A. 1991: 'The British Isles', in. W. van Zeist, K. Wasylikowa and K.-E. Behre (eds), Progress in Old World Palaeoethnobotany, Rotterdam, 299-334

Hall, A. 2004: Environmental Archaeology Bibliography, http://ads.ahds.ac.uk/catalogue/resources. html?eab_eh 2004

Hall, A.R., and Kenward, H.K. 1990: Environmental Evidence from the Colonia: General Accident and Rougier Street, The Archaeology of York 14(6), London/York

Hall, A.R., and Kenward, H.K. 2006: 'Development-driven archaeology: bane or boon for bioarchaeology?' Oxford Journal of Archaeology 25(3), 213-24

Harris, S.A., Robinson, J.P., and Juniper, B.E. 2002: 'Genetic clues to the origin of the apple', Trends in Genetics 18(18), 426-30

Hillman, G. 1981: 'Reconstructing crop husbandry practices from charred remains of crops', in R. Mercer ( ed.), Farming Practice in British Prehistory, Edinburgh, 123-62

Jones, G. 2005: 'Garden cultivation of staple crops and its implications for settlement location and continuity', World Archaeology 37(2), 164-76

Jones, G., Bogaard, A., Charles, M., and Hodgson, J.G. 2000: 'Distinguishing the effects of agricultural practices relating to fertility and disturbance: a functional ecological approach in archaeobotany', Journal of Archaeological Science 27, 1073-84

Jones, G., Bogaard, A., Halstead, P., Charles, M., and Smith, H. 1999: 'Identifying the intensity of crop husbandry practices on the basis of weed floras', Annual of the British School at Athens 94, 167-89

Jones, M. 1981: 'The development of crop husbandry', in M. Jones and G. Dimbleby (eds), The Environment of Man: the Iron Age to the Anglo-Saxon Period, BAR Brit. Ser. 87, Oxford, 95-127

Kenward, H., and Hall, A. 2007: 'Developer-funded archaeology and studies of biological remains', British Archaeology 94: 51 (April 2007)

Kreuz, A. 2000: 'Function and conceptual archaeobotanical data from Roman cremations', in J. Pearce, M. Millett and M. Struck (eds), Burial, Society and Context in the Roman World, Oxford, 45-51

Manen, J.-F., Bouby, L., Dalnoki, O., Marinval, P., Turgay, M., and Schlumbaum, A. 2003: 'Microsatellites from archaeological Vitis vinifera seeds allow a tentative assignment of the geographical origin of ancient cultivars', Journal of Archaeological Science 30, 721-9

Mattingly, D. 2006: An Imperial Possession. Britain in the Roman Empire, 54 BC-AD 409, London

Miller, J., Ramsay, S., and Alldritt, D. 2000: 'Charred and waterlogged plant macrofossils', in C. Haselgrove and R. McCullagh, An Iron Age Coastal Community in East Lothian: the Excavation of Two Later Prehistoric Enclosure Complexes at Fishers Road, Port Seton, 1994-5, Edinburgh, 40-9, 70-1, 207-33

Millett, M. 1992: The Romanization of Britain. An Essay in Archaeological Interpretation, Cambridge

Moffett, L, Ciaraldi, M., and Monckton, A. 1999: 'Charred plant remains and waterlogged plant remains', in S.C. Palmer, 'Archaeological excavations in the Arrow Valley, Warwickshire', Trans. Birmingham and Warwicks. Arch. Soc. 103, 162-73

Murphy, P. 2004: 'Carbonised plant remains', in R. Havis and H. Brooks, Excavations at Stansted Airport, 1986-91, Volume 1: Prehistoric and Romano-British, East Anglian Archaeology 107, Chelmsford, 327-39

OASIS: Online AccesS to the Index of archaeological investigationS http://ads.ahds.ac.uk/project/oasis/ england/ 
Petrucci-Bavaud, M., and Jacomet, S. 1997: 'Zur Interpretation von Nahrungsbeigaben in römerzeitlichen Brandgräber', Ethnographisches Archäologisches Zeitschrift 38, 567-93

Petrucci-Bavaud, M., Schlumbaum, A., and Jacomet, S. 2000: 'Bestimmung der botanischen Makroreste', in D. Hintermann (ed.), Der Südfriedhof von Vindonissa, Zug, 151-9

Pollmann, B., Jacomet, S., and Schlumbaum, A. 2005: 'Morphological and genetic studies of waterlogged Prunus species from the Roman vicus Tasgetium (Eschenz, Switzerland)', Journal of Archaeological Science 32, 1471-80

Probert, F. 1997: 'Report on the burnt grain', in A.G. Marvell and H.S. Owen-John, Leucarum. Excavations at the Roman Auxiliary Fort at Loughor, West Glamorgan 1982-84 and 1987-88, Britannia Monograph 12, London, 125-30

Robinson, M. 2002: 'Domestic burnt offerings and sacrifices at Roman and pre-Roman Pompeii, Italy', Vegetation History and Archaeobotany 11, 93-9

Threadgold, J., and Brown, T.A. 2003: 'Degradation of DNA on artificially charred wheat seeds', Journal of Archaeological Science 30, 1067-76

Tomlinson, P., and Hall, A. 1996: 'A review of the archaeological evidence for food plants from the British Isles: an example of the use of the ArchaeoBotanical Computer Database (ABCD)', Internet Archaeology 1 (http://intarch.ac.uk/journal/issue1/tomlinson_index.html)

Van der Veen, M. 1992: Crop Husbandry Regimes. An Archaeobotanical Study of Farming in Northern England $1000 B C-A D$ 500, Sheffield

Van der Veen, M. 2003: 'When is food a luxury?' World Archaeology 34(3), 405-27

Van der Veen, M. 2005: 'Gardens and fields: the intensity and scale of food production', World Archaeology $37(2), 157-63$

Van der Veen, M. 2007: 'Formation processes of desiccated and carbonised plant remains - the identification of routine practice', Journal of Archaeological Science (available on-line; expected paper publication summer 2007)

Van der Veen, M., and Fieller, N. 1982: 'Sampling seeds', Journal of Archaeological Science 9, 287-98

Van der Veen, M., and Livarda, A. in prep.: 'Formation processes of carbonized and waterlogged plant remains', Journal of Archaeological Science

Van der Veen, M., Livarda, A., and Hill, A. in press: 'The introduction of new food plants into Roman Britain - dispersal and social access', Environmental Archaeology

Yang, D.Y., and Watt, K. 2005: 'Contamination controls when preparing archaeological remains for ancient DNA analysis', Journal of Archaeological Science 32, 331-6

Zach, B. 2002: 'Vegetable offerings on the Roman sacrificial site in Mainz, Germany — short report on the first results', Vegetation History and Archaeobotany 11, 101-6 